\title{
Potential Applications of Arthrospira platensis Lipid-Free Biomass in Bioremediation of Organic Dye from Industrial Textile Effluents and Its Influence on Marine Rotifer (Brachionus plicatilis)
}

\author{
Ahmed E. Alprol 1, Ahmed M. M. Heneash 1, Mohamed Ashour 1,*(D), Khamael M. Abualnaja ${ }^{2}$, \\ Dalal Alhashmialameer ${ }^{2}$, Abdallah Tageldein Mansour ${ }^{3,4, * \mathbb{D}}$, Zaki Z. Sharawy ${ }^{1}$ (D) Mouhamed A. Abu-Saied ${ }^{5}$ (D) \\ and Abd El-Fatah Abomohra 6,7,*(D)
}

check for updates

Citation: Alprol, A.E.; Heneash, A.M.M.; Ashour, M.; Abualnaja, K.M.; Alhashmialameer, D.; Mansour, A.T.; Sharawy, Z.Z.; Abu-Saied, M.A.; Abomohra, A.E.-F. Potential Applications of Arthrospira platensis Lipid-Free Biomass in Bioremediation of Organic Dye from Industrial Textile Effluents and Its Influence on Marine Rotifer (Brachionus plicatilis) Materials 2021, 14, 4446. https:// doi.org/10.3390/ma14164446

Academic Editors: Rita Giovannetti and Marco Zannotti

Received: 7 July 2021

Accepted: 2 August 2021

Published: 8 August 2021

Publisher's Note: MDPI stays neutral with regard to jurisdictional claims in published maps and institutional affiliations.

Copyright: (c) 2021 by the authors. Licensee MDPI, Basel, Switzerland. This article is an open access article distributed under the terms and conditions of the Creative Commons Attribution (CC BY) license (https:/ / creativecommons.org/licenses/by/ $4.0 /)$.
1 National Institute of Oceanography and Fisheries (NIOF), Cairo 11516, Egypt; ah831992@gmail.com (A.E.A.); aheneash@yahoo.com (A.M.M.H.); zaki_sharawy@yahoo.com (Z.Z.S.)

2 Department of Chemistry, College of Science, Taif University, P.O. Box 11099, Taif 21944, Saudi Arabia; k.ala@tu.edu.sa (K.M.A.); Dsamer@tu.edu.sa (D.A.)

3 Animal and Fish Production Department, College of Agricultural and Food Sciences, King Faisal University, P.O. Box 420, Al-Ahsa 31982, Saudi Arabia

4 Fish and Animal Production Department, Faculty of Agriculture (Saba Basha), Alexandria University, Alexandria 21531, Egypt

5 Polymeric Materials Research Department, Advanced Technology and New Materials Research Institute, City of Scientific Research and Technological Applications (SRTA-CITY), New Borg El-Arab City, Alexandria 21934, Egypt; mouhamedabdelrehem@yahoo.com

6 New Energy and Environmental Laboratory (NEEL), School of Architecture and Civil Engineering, Chengdu University, Chengdu 610106, China

7 Botany and Microbiology Department, Faculty of Science, Tanta University, Tanta 31527, Egypt

* Correspondence: microalgae_egypt@yahoo.com (M.A.); amansour@kfu.edu.sa (A.T.M.); abomohra@yahoo.com (A.E.-F.A.)

Abstract: Arthrospira platensis is one of the most important cultured microalgal species in the world. Arthrospira complete dry biomass (ACDB) has been reported as an interesting feedstock for many industries, including biodiesel production. The A. platensis by-product of biodiesel production (lipidfree biomass; LFB) is a source of proteins, functional molecules, and carbohydrates, and can also be reused in several applications. The current study investigated the efficiency of ACDB and LFB in bioremediation of dye (Ismate violet $2 \mathrm{R}$, IV2R) from textile effluents. In addition, the potential of ACDB and LFB loaded by IV2R as a feed for Rotifer, Brachionus plicatilis, was examined. The surface of the adsorbents was characterized by SEM, FTIR, and Raman analysis to understand the adsorption mechanism. The batch sorption method was examined as a function of adsorbent dose (0.02-0.01 $\left.\mathrm{g} \mathrm{L}^{-1}\right)$, solution initial concentration (10-100 $\left.\mathrm{mg} \mathrm{L}^{-1}\right), \mathrm{pH}(2-10)$, and contact time (15-180 min). The kinetic studies and adsorption isotherm models (Freundlich, Langmuir, Tempkin, and Halsey) were used to describe the interaction between dye and adsorbents. The results concluded that the adsorption process increased with increasing ACDB and LFB dose, contact time (120 min), initial IV2R concentration ( $10 \mathrm{mg} \mathrm{L}^{-1}$ ), and acidity $\mathrm{pH}$ ( 2 and 6 , respectively). For the elimination of industrial textile wastewater, the ACDB and LFB sorbents have good elimination ability of a dye solution by $75.7 \%$ and $61.11 \%$, respectively. The kinetic interaction between dye and adsorbents fitted well to Langmuir, Freundlish, and Halsey models for LFB, and Langmuir for ACDB at optimum conditions with $\mathrm{R}^{2}>0.9$. In addition, based on the bioassay study, the ACDB and LFB loaded by IV2R up to $0.02 \mathrm{~g} \mathrm{~L}^{-1}$ may be used as feed for the marine Rotifer B. plicatilis.

Keywords: cyanobacterium; Arthrospira platensis NIOF17/003; bioremediation; Ismate violet 2R; adsorbent isotherm models; FTIR; rotifer bioassay 


\section{Introduction}

The release of untreated sewage waste and industrial emissions endangers marine ecosystems [1]. The effluents of textile industries are a complex, heavily colored, photolytically stable, and highly instable mixture of several contaminating materials; these substance are rich in dyes and other molecules, which induce color combined with the organic load conducing the breakdown of the whole ecological balance of the receiving aquatic system because they are very stable in natural environments [2]. The majorities of dyes are a possible health danger to all forms of life with long-term and occasional overexposure such as eczema, skin dermatoses, and allergic responses, and may affect the lungs, liver, immune system, vasco-circulatory system, and reproductive systems for animals and humans. In addition, they have a great effect on the photosynthetic activity of marine biota [3]. According to Mondal et al. [4], the standard and allowable levels of various parameters in textile industry wastewater must be $5.5-9$ for $\mathrm{pH}, 30 \mathrm{mg} \mathrm{L}^{-1}$ and $250 \mathrm{mg} \mathrm{L}^{-1}$ for BOD and COD parameters, respectively, in addition to $100 \mathrm{mg} \mathrm{L}^{-1}$ and $500 \mathrm{mg} \mathrm{L}^{-1}$ for TSS and TDS, while $1 \mathrm{mg} \mathrm{L}^{-1}$ for total residual chlorine is included. Permissible levels will vary by regulatory agency and municipality, according to information published by the American Water Works Association and the Water Pollution Control Federation of the United States [5], which indicated that any fungicide, pesticide, insecticide, rodenticide, herbicide, or fumigant discharged into any watercourse must not include any of the following issues as radioactive material: sawdust, garbage, timber, refuse, human or animal waste or solid matter, petroleum and/or other flammable solvent. Furthermore, the allowed effluent discharge limitations in controlled watercourses must not exceed around 7 Lovibond units for color, $5 \mathrm{mg} \mathrm{L}^{-1}$ for detergents (linear alkylate sulphonate such as methylene blue active chemicals), $1 \mathrm{mg} \mathrm{L}^{-1}$ (total) for grease and oil, and $0.5 \mathrm{mg} \mathrm{L}^{-1}$ for metals in total [5]. Turbinaria conoides was used by Rajeshkannan et al. [6] to study the biosorption of malachite green. Malachite green biosorption was detected to be highest at $30{ }^{\circ} \mathrm{C}$ and $\mathrm{pH}$ 8.0.

Textile dye effluent treatment techniques are becoming more difficult owing to increasing the industrial effluents disposal costs, diminishing resources of water, and stricter discharge rules that need decreased acceptable pollutant levels in wastewater streams; therefore, it is important to remove these dyes from industrial effluents before discharging into the environment [7]. Several physiochemical treatment methods for dye elimination have been investigated, including ozonation, the adsorption membrane process, electrodialysis, coagulation-flocculation, nano-filtration, trickling filters, membrane processes, reverse osmosis, and adsorption techniques [8]. Adsorption is one of the effective equilibrium separation technologies that so far have been successful in removing pollutants from wastewater owing to its simple design, high adsorption capacity, simplicity of operation, insensitivity, and flexibility to toxic pollutants [9].

Algal biomass is an attractive inbred bioactive substances that can be used in different industrial uses including aquaculture diet feed additive [10], aquaculture waterconditioner [11], plant growth biostimulants [12], the food industry [13], pharmaceuticals [14], antimicrobial substances [15], cosmetics [16], bioremediation [17], biodiesel [18,19], and crude bio-oil [20]. One of the most interesting applications is the production of biodiesel from microalgae due to the relatively high lipid productivity $[18,19]$. For many considerations, algal biomass, in the near future, will be the most important sustainable feedstock for the production of biodiesel, attributed to its high lipid percentage, which can be increased more than 40-fold greater than those of other plants [21]. Interestingly, the residual of the algal cells after oil extraction, i.e., lipid-free biomass, contains many bioactive compounds that can be used in different applications, such as aquafeeds, animal diet, or bioactive materials for pharmaceutical and cosmetic products [18].

The cyanobacterium filamentous blue green microalga Arthrospira platensis NIOF17/003 has various promising biotechnological applications. Over the world, this species is one of the most microalgal species that have great attention and have been widely cultured on a commercial scale [14,22]. The commercial production of A. platensis is generally developed 
around the world and increased from 48,000 tons in 2005 to over 89,000 tons in 2016 [23]. To develop strong commercial applications of native aquatic microorganisms, a scientific database of isolation, screening, molecular identification, growth conditions, biochemical composition, and bioactive substances must be created $[19,22]$. On the other hand, zooplanktons are considered as an important indicator for determining water pollution [24]. Moreover, many studies reported that the microalgal lipid-free biomass as a by-product from biodiesel production is a good source as feed for zooplanktons such as Artemia [19,25] and rotifer [22]. In addition, $A$. platensis contains many bioactive compounds which have different functional groups such as phosphate, hydroxyl, sulfate, carboxyl, and other charged groups which can intervene in pollutant binding. Therefore, it has been effectively utilized to eliminate toxic heavy metals and dyes from aqueous solutions [26].

Ismate violet $2 \mathrm{R}$ was chosen as a model compound in this research because of its wide variety of applications, which include dyeing silk, cotton, rayon, leather, paper, wood, and coating for paper stock and medical purposes, as well as its potential harm [27]. Furthermore, the Ismate violet $2 \mathrm{R}$ was classified as a sulfur dye based on their application, which is highly soluble in aqueous solution and has a higher negative charge density, as well as their adsorption preference for various adsorbents [28]. This could indicate that the adsorption process was influenced by the electrical connection between positively charged adsorbent surfaces and anionic dyes. Aromatic materials can be evaluated with sodium sulfide and re-oxidized to insoluble sulfur-containing chemicals on fibers as a sulfur coloring application method [29]. However, the application of lipid-free A. platensis biomass for dye removal and its consequent impact on rotifers were not previously evaluated. Consequently, the present study was conducted to investigate the phytoremediation possible of Arthrospira complete dry biomass (ACDB) and lipid-free biomass (LFB) of Arthrospira platensis NIOF17/003 (GenBank accession number: MW396472) in the removal capacity of Ismate violet $2 \mathrm{R}$ dye (IV2R) from textile effluents, either at a laboratory or pilot scale. Alternative kinetic adsorption and equilibrium isotherm models were used to determine the removal capacities of adsorbents (ACDB and LFB). Additionally, the current study investigated the bioassay and potential application of the adsorbents (ACDB and LFB) enriched with IV2R as a primary feedstock for the marine Rotifer, B. plicatilis.

\section{Materials and Methods}

\subsection{Arthrospira Platensis NIOF17/003 \\ 2.1.1. Algal Strain and Oil Extraction}

Arthrospira platensis NIOF17/003 adsorbent, isolated from El-Khadra alkaline-salty Lake in Wadi El-Natrun city, Egypt, $\left(30^{\circ} 13^{\prime} 546^{\prime \prime} \mathrm{E} ; 30^{\circ} 26^{\prime} 504^{\prime \prime} \mathrm{N}\right)$, has been recorded at the international GenBank with accession number: MW396472 [22]. A. platensis NIOF17/003 indoor cultivation, growth curve determination, harvesting, biochemical composition, lipid extraction, and biodiesel production were achieved as defined by Zaki et al. [22]. A. platensis NIOF17/003 was batch cultured for twelve days in $500 \mathrm{~mL}$ sterilized Zarrouk medium under controlled growth conditions of continuous illumination (3500-4000 Lux), temp $\left(28.5 \pm 2{ }^{\circ} \mathrm{C}\right)$, and incessant sterile aeration, with shaking at $80 \mathrm{rpm}$. At late exponential phase (day 8$)$, the biomass was obtained by centrifugation $\left(7000 \times g\right.$ for $\left.10 \mathrm{~min}^{-1}\right)$. Biochemical composition, lipid extraction, lipid productivity, and the physicochemical properties of FAMEs of the biodiesel of $A$. platensis NIOF17/003 were determined and calculated as described by Zaki et al. [22]. After oil extraction, Arthrospira complete dry biomass (ACDB) and lipid-free biomass (LFB) of A. platensis NIOF17/003 were dried for $48 \mathrm{~h}$ at $55^{\circ} \mathrm{C}$ and conserved at $10^{\circ} \mathrm{C}$ for additional characterizations.

\subsubsection{Characterization of $\mathrm{ACDB}$ and LFB}

The dried A. platensis NIOF17/003 biomass was milled by (Wiley Mill Standard, 03, USA) then sieved to minor particle size with the average of $75 \mu \mathrm{m}$, then suspended in distilled water and vortexed for $20 \mathrm{~min}$ at 10,000 rpm (Dremel, 1100-01, Brazil). These conditions were created by the previous preliminary examinations; in addition, the size 
distribution was not affected by the $\mathrm{pH}$. The morphological investigations of the adsorbents (ACDB and LFB) were carried out by scanning electron microscope (SEM), (JEOL JSM 6360 LA). Furthermore, Fourier transform infrared (Shimadzu FTIR-8400 S, Kyoto, Japan) and Raman analysis spectrophotometry (a Senterra Raman spectrometer, USA) were used to measure the influence of the dye on biomass.

\subsection{Dye Solution Preparation}

Stock solution of the dye Ismate violet $2 \mathrm{R}$ (IV2R) was archived by dissolving the accurately balanced dye in distilled water at $1000 \mathrm{mg} \mathrm{L}^{-1}$ of concentration, without additional purification. The specification of IV2R is presented in Table 1 . The investigational mixtures were achieved by diluting the IV2R dye stock mixture to the accurate proportions to obtain various preliminary concentrations.

Table 1. characteristics of physical and chemical for ISMATE violet 2R [30].

\begin{tabular}{ccc}
\hline Characteristics & Value \\
\hline $\begin{array}{c}\text { Dye name } \\
\text { (a common name) }\end{array}$ & Ismate violet 2R \\
\hline Wavelength $(\lambda$ max $)$ & $550 \mathrm{~nm}$ \\
\hline Mol. wt. & \\
\hline Molecular formula & & \\
\hline Color Index name &
\end{tabular}

\subsection{Adsorption Experiments}

The effects of contact time $(15,30,45,60,120$, and $180 \mathrm{~min}), \mathrm{pH}(2,4,6,8$, and 10), initial IV2R dye concentration $\left(10,20,30,40,50\right.$, and $\left.100 \mathrm{mg} \mathrm{L}^{-1}\right)$ [31], and different adsorbent concentrations $\left(0.02,0.04,0.06,0.08\right.$, and $\left.0.1 \mathrm{~g} \mathrm{~L}^{-1}\right)$ of either ACDB or LFB were examined for the IV2R removal. The particular conditions have been cited in the related plots. The experiments were performed in triplicates by batch technique to find the equilibrium data. The reaction mixture containing $10 \mathrm{~mL}$ of dye solution was shacked at room temperature $\left(25 \pm 2{ }^{\circ} \mathrm{C}\right)$ at $110 \mathrm{rpm}$ under the specified conditions. For these experiments, amounts of dye solutions $\left(10 \mathrm{mg} \mathrm{L}^{-1}\right)$ were fixed and selected in the study of the effects of $\mathrm{pH}$, contact time, and adsorbent doses. The concentrations of dye in the solution were assessed quantitatively, as stated by Lambert-Beer law [28], by linear equations achieved through plotting a calibration curve for IV2R dye at concentrations series and absorbance at $550 \mathrm{~nm}$. Both of adsorption capacity $\left(\mathrm{q}_{\mathrm{e}}\right)$ and dye removal percentages were calculated as described previously [26] by the following equations:

$$
\begin{aligned}
& \text { Percentage removal }(\%)=\frac{\left(C_{i}-C_{f}\right)}{C_{i}} \times 100 \\
& \text { Adsorption capacity }\left(q_{e}\right)=\frac{\left(C_{i}-C_{f}\right) \times V}{W}
\end{aligned}
$$


which: $\mathrm{C}_{\mathrm{i}}$ and $\mathrm{C}_{\mathrm{f}}$ are the primary concentration at initial time and the final concentration IV2R at certain period $\left(\mathrm{mg} \mathrm{L}^{-1}\right)$, respectively, while $\mathrm{V}$ is the volume of the dye mixture (L); in addition, $\mathrm{W}$ is the weight of the dry adsorbent $(\mathrm{g})$.

\subsection{Adsorption Isotherm Experiments}

The extent of elimination of IV2R from aqueous solution strongly depends on the preliminary dye concentrations; therefore, different IV2R concentrations of $10-100 \mathrm{mg} \mathrm{L}^{-1}$ were investigated at constant parameters of $\mathrm{pH} 6,30^{\circ} \mathrm{C}, 3 \mathrm{~h}$, with $0.2 \mathrm{~g}$ of $\mathrm{ACDB}$ and $\mathrm{LFB}$, at $150 \mathrm{rpm}$ which was adequate to reach equilibrium [26]. The data was fitted and calculated into the following isotherm experiments: Langmuir, Freundlich, Tempkin, and the Halsey model.

\subsubsection{Langmuir Model}

The Langmuir model is presented by the following a mathematical expression [32]:

$$
\mathrm{q}_{\mathrm{e}}=\mathrm{q}_{\max } \mathrm{bCe} /(1+\mathrm{bCe})
$$

where: $\mathrm{q}_{\max }$ is the higher sorption capacity $\left(\mathrm{mg} \mathrm{g}^{-1}\right)$ consistent to the saturation capacity (representing whole binding sites of adsorbent) and $b$ is the coefficient regarding to the affinity among biomass and dyes ions $\left(\mathrm{L} \mathrm{mg}^{-1}\right)$; in addition, $\mathrm{b}$ is the energy of the sorption process.

The relationship of this model can be achieved from plotting curve $\left(1 / q_{e}\right)$ vs. $\left(1 / C_{e}\right)$ :

$$
1 / \mathrm{qe}=1 /\left(\mathrm{bq}_{\max } \mathrm{C}_{\mathrm{e}}\right)+1 / \mathrm{q}_{\max }
$$

where $\mathrm{b}$ and $\mathrm{q}_{\max }$ are calculated from slope and intercept of the linear equation, respectively.

\subsubsection{Freundlich Model}

For the examinable the ability of Freundlich model to fit the experimental data, via plotting a curve of $\log q_{e}$ with respect to $\log C_{e}$ was used to create the slope of $n$ and the intercept value of $\mathrm{K}_{\mathrm{f}}$. Moreover, the Freundlich model could be definitely linearized through plotting it in the following logarithmic Equation [33]:

$$
\log \mathrm{q}_{\mathrm{e}}=\log \mathrm{K}_{\mathrm{f}}+1 / \mathrm{n} \log \mathrm{C}
$$

Freundlich constants $\mathrm{K}_{\mathrm{f}}$ and $\mathrm{n}$ have been determined by the isotherm equation according to Equation (5).

\subsubsection{Temkin Model}

Tempkin linear isotherm is given as follows [34]:

$$
\mathrm{q}_{\mathrm{e}}=\mathrm{B} \ln \mathrm{A}+\mathrm{B} \ln \mathrm{C}_{\mathrm{e}}
$$

where: $\mathrm{B}=\mathrm{RT} / \mathrm{b}$, A shows the equilibrium binding constant $\left(\mathrm{Lg}^{-1}\right)$ correlated to the higher binding energy, $\mathrm{b}\left(\mathrm{J} \mathrm{mol}^{-1}\right)$ is a constant corresponding to heat of adsorption, while $\mathrm{B}=(\mathrm{RT} / \mathrm{b})\left(\mathrm{J} \mathrm{mol}^{-1}\right)$ is the Tempkin constant and the heat of the sorption process, $\mathrm{R}$ is the gas constant (8.314 $\mathrm{J} \mathrm{mol}^{-1} \mathrm{~K}$ ), and $\mathrm{T}$ is the absolute temperature (Kelvin). The sorption results can be analyzed according to Tempkin Equation (6). Therefore, a plot curve of $q_{e} v s$. $\ln C_{e}$ allows the examination of the Tempkin isotherm constants $A$ and $B$ from the slope and intercept. 


\subsubsection{The Halsey Isotherm Model}

The Halsey equation is appropriate for a multilayer sorption process; in addition, the fitting of the Halsey model can be heteroporous solids [35]. The Halsey model could be applied in the following Equation:

$$
\operatorname{Ln} \mathrm{q}_{\mathrm{e}}=\frac{1}{\mathrm{n}} \operatorname{Ln} \mathrm{K}+\frac{1}{\mathrm{n}} \operatorname{Ln} \mathrm{C}_{\mathrm{e}}
$$

where: $\mathrm{K}$ and $\mathrm{n}$ are Halsey constants.

\subsection{Adsorption Kinetics}

Kinetic studies are achieved in $50 \mathrm{~mL}$ conical flasks at liquid of $\mathrm{pH} 2,0.1 \mathrm{~g}$ of adsorbent was mixed separately with $50 \mathrm{~mL}$ of IV2R mixture of $10 \mathrm{mg} \mathrm{L}^{-1}$ concentrations and the solution was agitated at room temperature under requisite time intervals viz. 15, 30, 45, 60, 120 , and $180 \mathrm{~min}$.

\subsubsection{Pseudo-First Order Kinetic}

The linear form of the generalized of pseudo-first order equation [34] is given by the following equation:

$$
\mathrm{dq} / \mathrm{d}_{\mathrm{t}}=\mathrm{K}_{1}\left(\mathrm{q}_{\mathrm{e}}-\mathrm{q}_{\mathrm{t}}\right)
$$

where: $\mathrm{q}_{\mathrm{e}}\left(\mathrm{mg} \mathrm{g}^{-1}\right)$ is the amount of dye adsorbed at equilibrium, $\mathrm{q}_{\mathrm{t}}\left(\mathrm{mg} \mathrm{g}^{-1}\right)$ is the quantity of dyes adsorbed at time $\mathrm{t}$, and $\mathrm{K}_{1}\left(\mathrm{~min}^{-1}\right)$ is expressed as the pseudo first-order rate constant. The integrating equation is given by the following equation:

$$
\log \left(q_{e} / q_{e}-q_{t}\right)=k_{1} t / 2.303
$$

The equation of pseudo-first order is given by the following formula in the linear equation:

$$
\log \left(q_{e}-q_{t}\right)=\log q_{e}-K_{1} t / 2.303
$$

The $\mathrm{q}_{\mathrm{e}}$ and $\mathrm{K}_{1}$ values were calculated from the intercept and slope of the linear plots of $\log \left(q_{e}-q_{t}\right)$ verses $t$ at an initial dye concentration of $10 \mathrm{mg} \mathrm{L}^{-1}$.

\subsubsection{Pseudo-Second Order Kinetic Model}

The pseudo-second order equation was expressed as following [36]:

$$
\mathrm{dq} / \mathrm{d}_{\mathrm{t}}=\mathrm{k}_{2}\left(\mathrm{q}_{\mathrm{e}}-\mathrm{q}_{\mathrm{t}}\right)^{2}
$$

where: $\mathrm{k}_{2}\left(\mathrm{~g} \mathrm{mg}^{-1} \mathrm{~min}^{-1}\right)$ indicates the pseudo-second order rate constant. The integrating equation for the boundary conditions of $t=0$ to $t$ and, correspondingly, $q_{t}=0$ to qt presented:

$$
1 /\left(\mathrm{q}_{\mathrm{e}}-\mathrm{q}_{\mathrm{t}}\right)=1 / \mathrm{q}_{\mathrm{e}}+\mathrm{k}_{2}
$$

The equation of the pseudo-second order was adjusted to obtain a linear form as described by Ozacar and Şengil [37] as the following:

$$
\mathrm{t} / \mathrm{q}_{\mathrm{t}}=1 / \mathrm{k}_{2} \mathrm{qe}^{2}+\mathrm{t} / \mathrm{qe}_{\mathrm{e}}
$$

Plots of $\left(t / q_{t}\right)$ against $(t)$ can provide a linear correlation from which the values of parameters $\mathrm{q}_{\mathrm{e}}$ and $\mathrm{K}_{2}$ can be calculated from the slope and intercept, respectively.

\subsubsection{The intraparticle Diffusion Model}

The intraparticle diffusion equation is explored by the following equation:

$$
q_{t}=K_{\text {dif }} t^{1 / 2}+C
$$


where: $\mathrm{C}$ is the intercept; in addition, $\mathrm{K}_{\mathrm{dif}}\left(\mathrm{mg} \mathrm{g}^{-1} \mathrm{~min}^{-0.5}\right)$ reflects the intraparticle diffusion rate constant.

\subsection{Application of $A C D B$ and LFB on Actual Wastewater}

In order to detect the efficiency of ACDB and LFB to decolorize textile effluents, textile wastewater was collected in sterile containers from Misr company for textile dyeing and printing located in the Al-Mahala Al-Kobra (Gharbia, Egypt) and mixed with wastewater sample collected from El-Emoum drain, neighboring Lake Maruit, Alexandria, Egypt, which contains industrial sewage and agriculture waste. Deionized water including the analogous concentration of dyes was prepared to apply as a control to evaluate the influence of adsorbent on IV2R dye elimination. The application of ACDB and LFB to remove IV2R from wastewater was carried out using the optimum experimental conditions for each ACDB and/or LFB.

\subsection{Bioassay Test}

The harvested biomass (ACDB and/or LFB) that was loaded with IV2R was used as aqua-feed to determine its toxic potential on the marine Rotifera, Brachionus plicatilis, (L-type, mean length of $180 \mu \mathrm{m}$ ). Prior to the bioassay test, B. plicatilis were maintained and cultured under controlled conditions $\left(23^{\circ} \mathrm{C}, 30 \mathrm{ppt}, \mathrm{pH} 7.5\right.$, continuous thin aeration, while being supplemented with the native green microalga Nannochloropsis oceanica NIOF15/001 [19], at a density of $5.5 \times 10^{6}$ cells ml $^{-1}$ day $^{-1}$. Rotifer individuals were collected from the culture tanks, starved for $24 \mathrm{~h}$ to reach complete gut discharge, and then distributed into plastic jars filled with $500 \mathrm{~mL}$ of filtered seawater, three replicates for each level. The bioassay experiment was conducted for $72 \mathrm{~h}$ under constant conditions $\left(23^{\circ} \mathrm{C}\right.$, $30 \mathrm{ppt}, \mathrm{pH}$ value 7.5, and without aeration). In the present study, the effect of different doses $(0.02,0.05,0.10$, and $0.20 \mathrm{~g})$ of ACDB and LFB, those loaded with IV2R compared to the same levels without loading IV2R on rotifer population growth, rotifer mortality, female carry eggs population, and the mortality of female carry eggs were investigated. Using an optical microscope, the rotifer tested parameters were measured using a Sedgwick-Rafter counting cell as previously described [22]. The rotifer population was calculated as an increase or decrease of the individual total number while the initial stocking density of rotifer was $17,664 \pm 1154$ individual $\mathrm{L}^{-1}$. The rotifer carry eggs population was calculated as the number of rotifer female carry eggs, while the initial stocking density of rotifer female carry eggs was $14,500 \pm 1850$ females $\mathrm{L}^{-1}$. Moreover, total mortality and that of female carry eggs were investigated as dead individuals and females, respectively, during samples investigation under the microscope.

\subsection{Statistical Analysis}

The homoscedasticity suspicions, normality, and endogeneity of the presented data (mean \pm standard deviation, $S \mathrm{SD}, \mathrm{n}=3$ ) were affirmed before the statistical analysis which was performed via the SPSS program (IBM, v. 20, Armonk, NY, USA). All estimated variables were applied, at a significant level $(p<0.05)$, to a study of variance (ANOVA), Duncan's multiple range examinations, and the least significant difference (LSD) tests.

\section{Results and Discussion}

\subsection{Adsorbents Characterization}

\subsubsection{FTIR Analysis}

Figure 1 shows the FTIR spectra of A. platensis (ACDB and LFB) before and after adsorption, which revealed broad, intense absorption peaks at $3271.8-3856.8 \mathrm{~cm}^{-1}$. It displays the stretching vibration of $\mathrm{NH}$ and $\mathrm{O}-\mathrm{H}$ groups. In addition, the intense band observed at 2917 and $2922 \mathrm{~cm}^{-1}$ indicates the extending vibrations of asymmetric $\mathrm{CH}$ bond of methoxy, methylene, and methyl groups. The presence of peaks around $2349.79 \mathrm{~cm}^{-1}$ might be owing to presence of amide and thiol S-H stretching. Furthermore, the absorption peaks at $2067.80 \mathrm{~cm}^{-1}$ refer to $(C \equiv C)$. The absorbance band at 1635.36 and $1628.89 \mathrm{~cm}^{-1}$ 
can be ascribed to the existence of carbonyl $\mathrm{C}=\mathrm{O}$ stretching vibration of the carboxyl groups and aromatic $C=C$ ring stretching. The intense band seen at 1540.36 and $1521.77 \mathrm{~cm}^{-1}$ showed the presence of $\mathrm{N}-\mathrm{H}$ bond and $\mathrm{C}=\mathrm{C}$ stretching, which may be attributed to the presence of aromatics. Moreover, there are numerous shoulders and small bands in the scope of the region between 1444.55 and $1230.97 \mathrm{~cm}^{-1}$ refer to the aromatic rings, C-H bending and C-O stretching vibration absorption peaks [2].

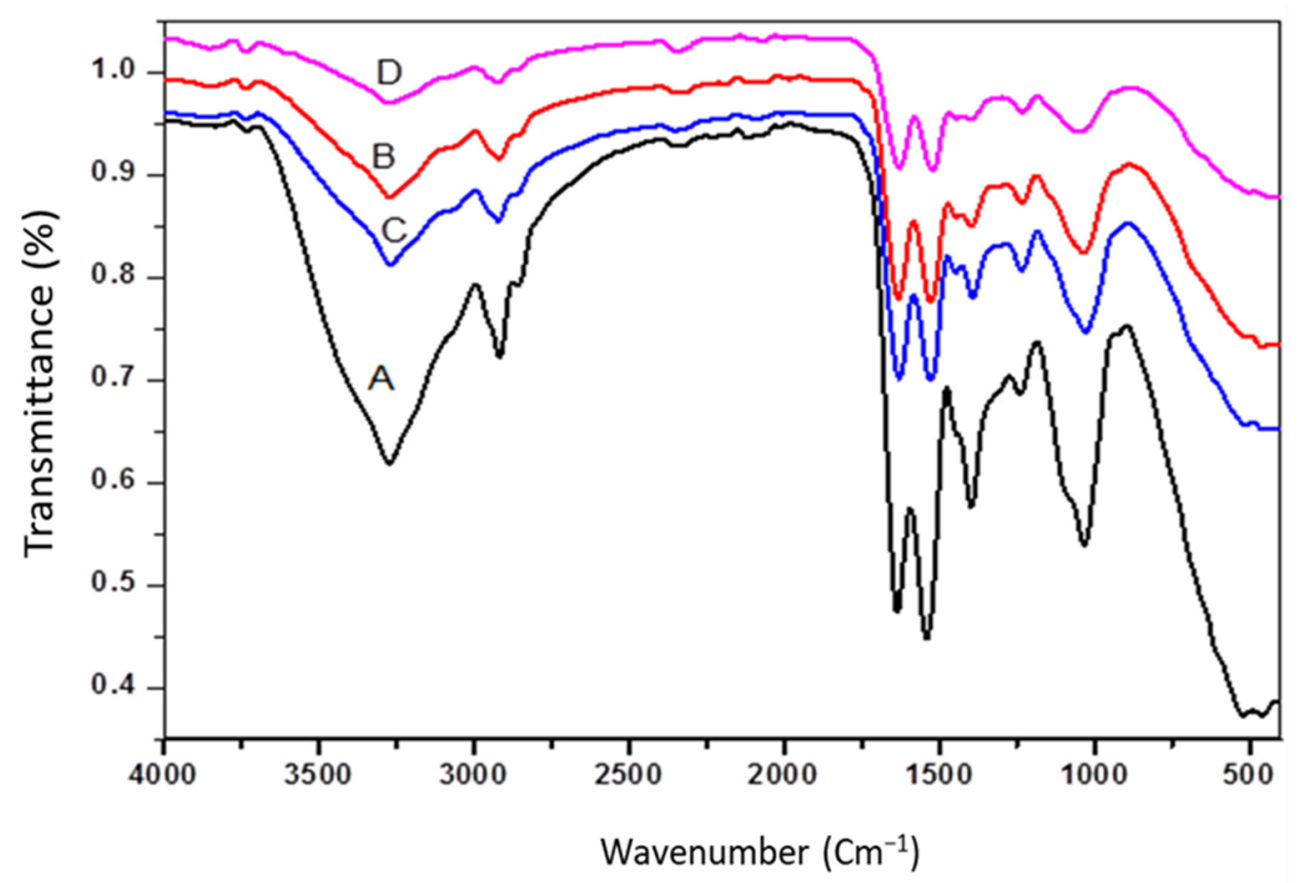

Figure 1. FTIR spectra: (A) ACDB before adsorption; (B): ACDB after adsorption; (C) LFB before adsorption; (D) LFB after adsorption.

$\mathrm{C}=\mathrm{O}$ stretching in the alginate extraction was attributed to the intensity of the band at 1391,1396 , and $1397 \mathrm{~cm}^{-1}$, while the band at 1632, 1635, and $1628 \mathrm{~cm}^{-1}$ remained intense, attributed to interference between the carboxylate and primary amide bands. So, alginate traces in the adsorption capacity of the adsorbents for the removal process can be attributed to the amides. The spectrum of S. linifolium polysaccharide contained a short peak at 1239 and $1233 \mathrm{~cm}^{-1}$, which was attributed to the presence of sulfated ester groups $(\mathrm{S}=\mathrm{O})$, which is a specific component in fucoidan, and at 1032 and $1039 \mathrm{~cm}^{-1}$, which corresponded to the $\mathrm{S}=\mathrm{O}$ stretch of the sulfated polysaccharides or the $\mathrm{C}-\mathrm{N}$ stretching of aromatic amine group [38]. All these suggested that the polysaccharide of tested seaweeds may be fucoidan and alginate. Table 2 showed that the formation of new peaks, disappearance of some peaks, changes in absorption intensity, or shift in wavenumber of functional groups before and after adsorption, which could be attributed to the interaction of ions in the dye with the active sites of two adsorbents. Furthermore, other studies suggest that there is no noticeable chemical reaction occurring during the adsorption process. As a result, the dye adsorption in this example was most likely electrostatically and physically motivated. The outcome data was compared with the absorption peaks before and after adsorption that is listed in IR spectroscopy, as shown in Table 2.

In that context, the interaction of IV2R with the adsorbent takes place at $\mathrm{NH}_{2}, \mathrm{C}=\mathrm{O}$, $\mathrm{COOH}$, and $\mathrm{OH}$ groups, and on the aromatic group existing in the adsorbents, which showed a reduction in those peaks after adsorption. 
Table 2. FT-IR spectrum of the tested ACDB and LFB, before and after adsorption.

\begin{tabular}{|c|c|c|c|}
\hline \multicolumn{2}{|c|}{ ACDB } & \multicolumn{2}{|c|}{ LFB } \\
\hline $\begin{array}{l}\text { Before Adsorption } \\
\left(\mathrm{cm}^{-1}\right)\end{array}$ & $\begin{array}{l}\text { After Adsorption } \\
\qquad\left(\mathrm{cm}^{-1}\right)\end{array}$ & $\begin{array}{l}\text { Before Adsorption } \\
\qquad\left(\mathrm{cm}^{-1}\right)\end{array}$ & $\begin{array}{l}\text { After Adsorption } \\
\qquad\left(\mathrm{cm}^{-1}\right)\end{array}$ \\
\hline 457.77 & 1034.97 & 448.73 & 1047.13 \\
\hline 1032.15 & 1233.58 & 1029.56 & 1230.93 \\
\hline 1239.13 & 1396.38 & 1233.22 & 1397.83 \\
\hline 1396.98 & 1443.85 & 1391.72 & 1444.55 \\
\hline 1540.10 & 1526.94 & 1446.89 & 1521.77 \\
\hline 1635.36 & 1632.08 & 1527.21 & 1628.89 \\
\hline 2917.13 & 2329.33 & 1628.75 & 2067.80 \\
\hline 3273.47 & 2929.06 & 2921.64 & 2349.79 \\
\hline 3730.69 & 3270.67 & 3269.13 & 2922 \\
\hline- & 3734.47 & 3732.82 & 3271.80 \\
\hline \multirow[t]{2}{*}{-} & 3847.56 & - & 3735.70 \\
\hline & & - & 3856.80 \\
\hline
\end{tabular}

\subsubsection{Raman Spectral Analysis}

The vibrational data describe the symmetry of molecules and chemical bonds which could be known from Raman spectroscopy analysis of A. platensis (ACDB and LFB), as shown in (Figure 2). Min et al. [7] reported that algae cells mainly comprise five kinds of biomolecules: nucleic acids, carbohydrates, proteins, lipids, and pigments. Each type has its own characteristic signature of Raman spectrum. The absorption peaks at 1644 and $1642 \mathrm{~cm}^{-1}$ are due to $\mathrm{C}=\mathrm{N}$ vibration group and the $\mathrm{G}$ band refers to the first-order scattering of the $\mathrm{E}_{2} \mathrm{~g}$ phonon of $\mathrm{sp}^{2} \mathrm{C}$ molecules, while the band at $1513 \mathrm{~cm}^{-1}$ is ascribed to the $C$ band. The bands at $73.85-75.01 \mathrm{~cm}^{-1}$ correspond to the lattice vibrations in the crystals, which originate from dye ions. The band between $3361.71 \mathrm{~cm}^{-1}$ refer to $\mathrm{N}-\mathrm{H}$ stretching vibrations. The absorption peaks at $3640-4176.30 \mathrm{~cm}^{-1}$ are attributed to $v(\mathrm{O}-\mathrm{H})$, while peaks at $1820-1893 \mathrm{~cm}^{-1}$ are related to the skeletal vibrations of $C=C$ stretching mode. The absorption peak at $1753-1755 \mathrm{~cm}^{-1}$ is representative for $\mathrm{C}=\mathrm{O}$ groups in carboxyl and carbonyl moieties. In the ACDB, there are disappearances of vibration bands at 3779.79 , 3640.87 , and $3170.64 \mathrm{~cm}^{-1}$; however, the vibration peaks appeared at $4176.30,3361.14$, $3237.91 \mathrm{~cm}^{-1}, 1987.85,1880.05,1754.81,1644.57$, and $74.07 \mathrm{~cm}^{-1}$, recorded after ACDB adsorption. The formation of new peaks of LFB at 4402.48 and $1155.39 \mathrm{~cm}^{-1}$ was caused by $-\mathrm{C}=\mathrm{N}$ group stretching. 


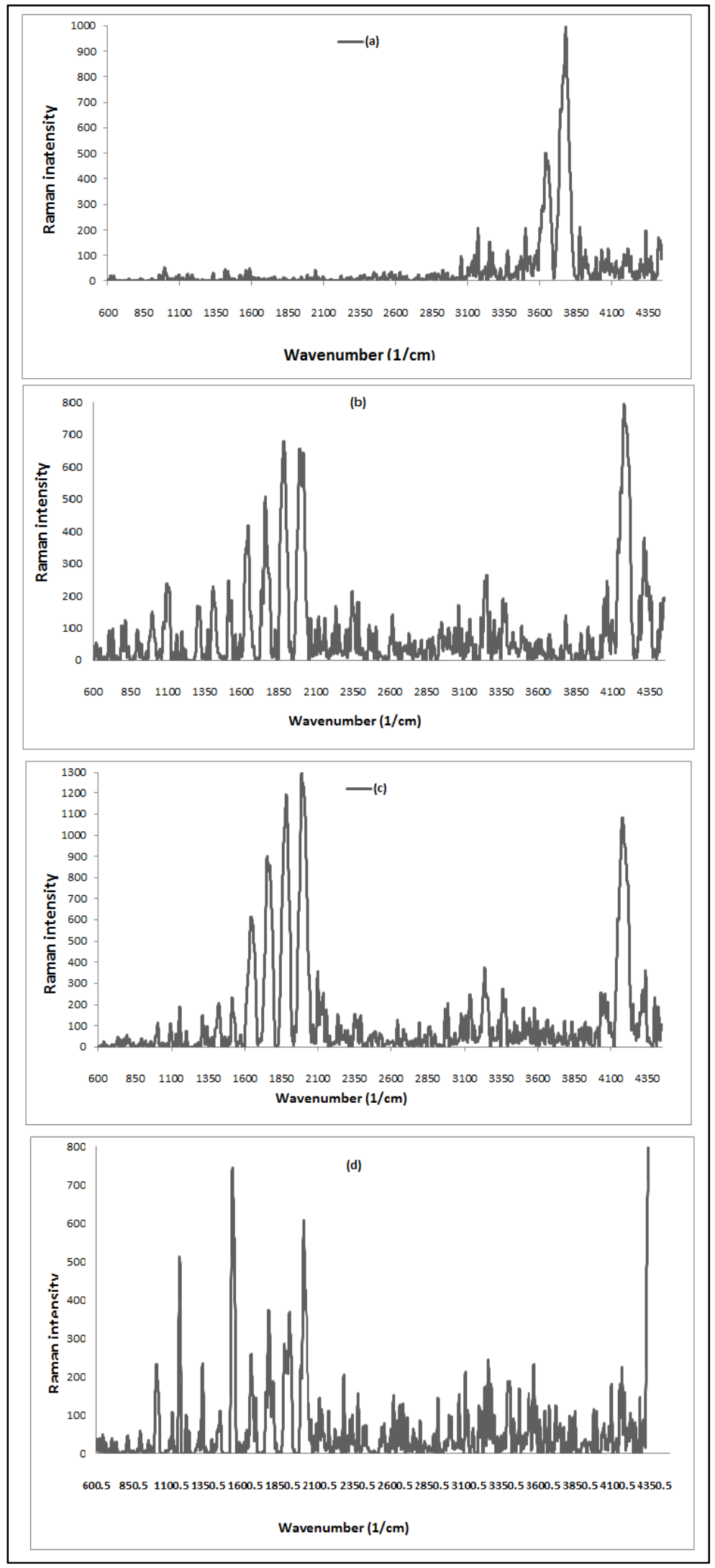

Figure 2. Raman spectrum for spectra for: ACDB before adsorption (a); ACDB after adsorption (b); LFB before adsorption (c); LFB after adsorption of IV2R dye (d). 


\subsubsection{Scanning Electron Microscope}

The visualization of the morphology surface of ACDB and LFB before and after adsorption is one of the factors used to evaluate the porosity and average diameter of microalgae particles. The morphology and diameter of the A. platensis surface was analyzed by SEM before and after IV2R adsorption (Figure 3). Figure 3A shows the SEM micrograph of ACDB before exposure to dye solution, where cells were agglomerates and had certain dimensions. The surface of $\mathrm{ACDB}$ after adsorption showed irregular and uneven surface texture in addition to minor changes of morphology with shrinking and sticking (Figure 3B). Figure 3E shows the SEM image of LFB before adsorption, where particles had certain dimensions, organized and well-shaped. However, the morphology of LFB after adsorption was in the form of a helix, tube, and unfederated distribution with a high porosity (Figure 3F). The change in the cell wall matrix for LFB indicates the increased surface adsorption of dyes. In contrast, the average diameter of ACDB before adsorption of IV2R dye was $194.97 \mathrm{~nm}$, while the mean diameter was $160.69 \mathrm{~nm}$, a little lower than ACDB before adsorption (Figure 3C,D). Figure 3G,H display the diameter distribution of LFB before and after adsorption, which were in the range of 100-260, and 120-240 nm, respectively, with average diameters of 176.09 and $183.87 \mathrm{~nm}$ for both LFB before and after adsorption, respectively. The changes in the morphological state and the diameter in LFB may be due to the hydrolysis operation of lipid extraction using concentrated chloroform and methanol. The porosity and pore size of different materials play an essential role for the elimination of dye $[30,39]$.

\subsection{Influence of Operational Parameters on Adsorption \\ 3.2.1. Adsorbent Dosage}

The influence of ACDB and LFB dosage (liquid to solid ratio) on color elimination of the IV2R dye under different biomass dosages was examined (Figure 4). The results showed that the color of dye augmented with the dosage increased from 0.02 to $0.1 \mathrm{~g} \mathrm{~L}^{-1}$ of adsorbent amounts. The percentages of IV2R removal by ACDW adsorbent increased from 56.3 to $84.13 \%$, while using LFB enhanced the removal from 58 to $87.2 \%$ using $0.02 \mathrm{~g}$ to $0.1 \mathrm{~g}$, respectively. This may be due to a greater availability of surface area or the exchangeable sites at a higher quantity of adsorbent dosage for the complexation of dye ions. In the same way, reduced dye removal is described at very high adsorbent doses owing to incomplete aggregation of adsorbents, in addition to a reduction in the average distance among obtainable adsorption sites [28]. Furthermore, electrostatic interactions between cells could be a major factor in the uptake of biomass-dependent dyes. If the distance between the cells is greater, a huge amount of dye ions is biosorbed; otherwise, a small amount of adsorbent is utilized, which is sufficient for sorption to occur [40]. Even though an increased adsorbent dose has a reducing role on the sorption capacity of a desorbent. Algae have a high surface area and a high binding affinity during biosorption, which increases their adsorption capacity [41]. The algal cell surface contains functional groups such as hydroxyl, carboxylate, amino, and phosphate, which are responsible for the removal of pollutants from wastewater [26]. 

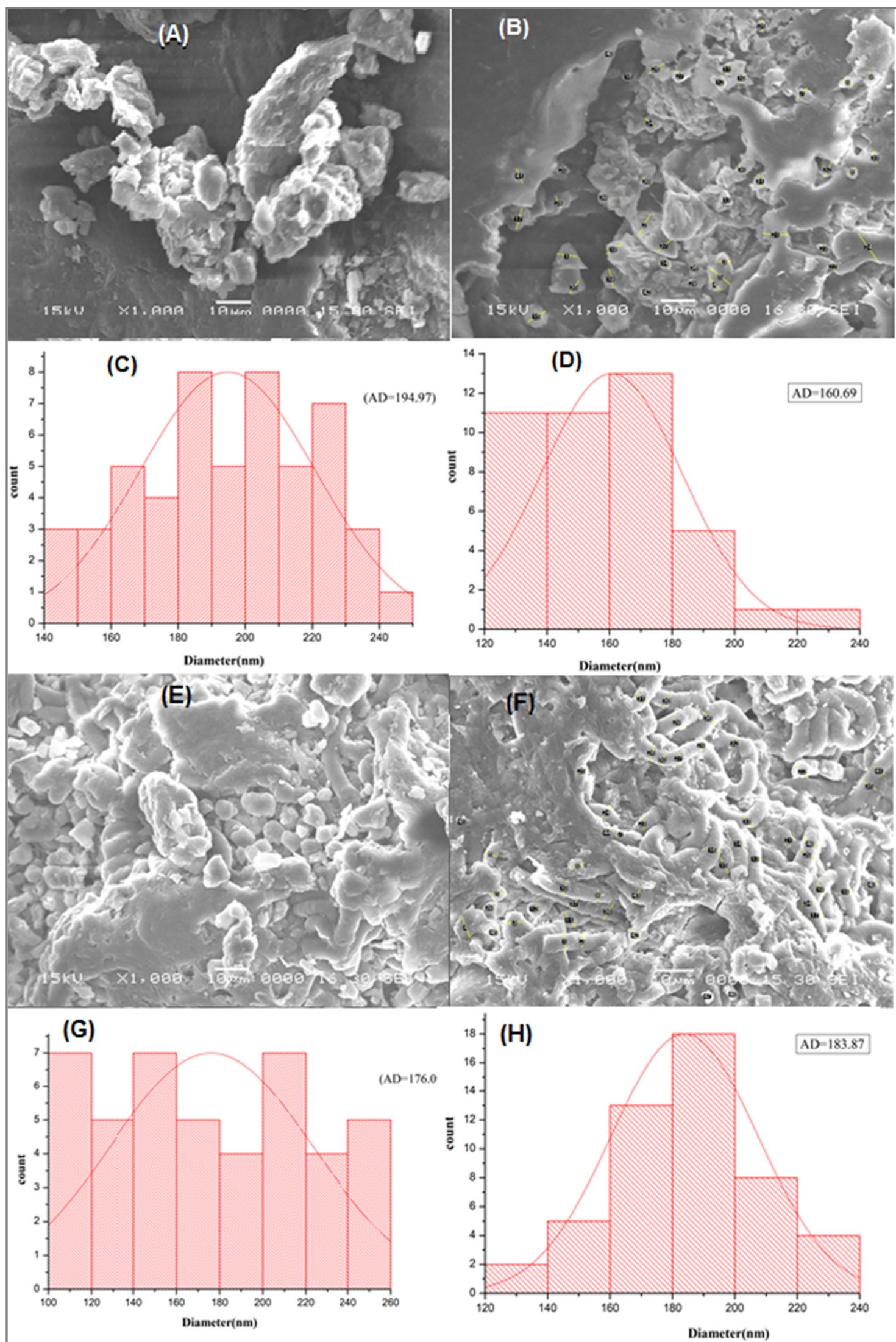

Figure 3. SEM pictures of ACDB before adsorption (A), after adsorption (B), and LFB before adsorption (E); LFB after adsorption $(\mathbf{F})$, and the corresponding diameter distributions of $(\mathbf{C}, \mathbf{D}, \mathbf{G}$, and $\mathbf{H}$, respectively). 


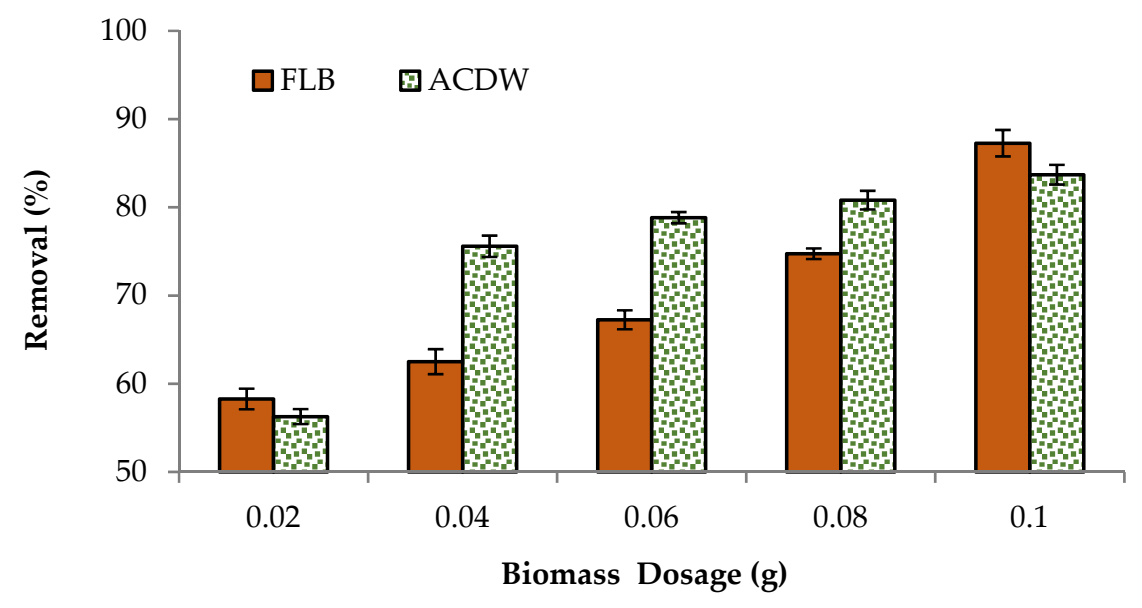

Figure 4. Influence of adsorbent dosage on the elimination efficiency of IV2R dye.

\subsubsection{Initial Dye Concentration}

The results of the effect of initial concentrations of dye on the sorption uptake of IV2R are shown in Figure 5. Six initial dye concentrations $\left(10,20,30,40,50\right.$, and $100 \mathrm{mg} \mathrm{L}^{-1}$ ) were used at a constant adsorbent amount of $0.04 \mathrm{~g}$ for $2 \mathrm{~h}$ at room temperature. As Ismate violet $2 \mathrm{R}$ adsorbed relatively well on this medium with a contact time of 120 min, which corresponds to removal rates of 83.3 and $56.4 \%$ for ACDB and LFB, respectively, the initial concentration of $10 \mathrm{mg} \mathrm{L}^{-1}$ IV2R dye was selected to be used in real wastewater. The number of functional groups available reduced as the initial dye concentration increased. The percentage uptake of dye reduced from $83.3 \%$ to $37 \%$ and $56.4 \%$ to $36.91 \%$ by augmentation of the dye concentration from 10 to $100 \mathrm{mg} \mathrm{L}^{-1}$, for ACDB and LFB, respectively. It has been found that the adsorption rate of IV2R dye is high at the beginning then reduces gradually until the saturation stages were wholly reached after a definite concentration of dye for both the adsorbent biomasses. The number of accessible functional groups reduces as the initial dye concentration increases, as seen by the decrease in percentage sorption as the initial dye ions concentrations increase, due to the fact that the amount of sorbed dye increases in the meantime [8]. This behavior may be due to the fact that at lower concentrations there were sufficient active adsorbent sites for adsorption of presently available dye molecules, but at higher concentrations, due to the inadequate ratio of active sites with dye molecules, adsorption is less [42].

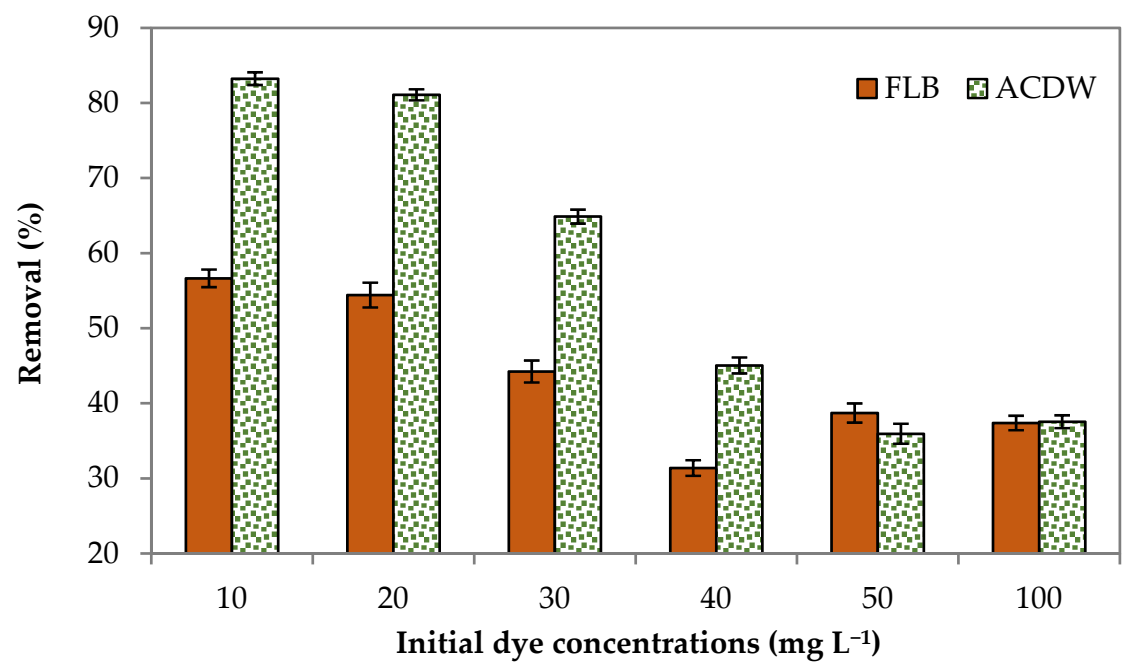

Figure 5. Influence of initial dye concentrations on elimination efficiency of IV2R dye. 


\subsubsection{Contact Time $\mathrm{mg} \mathrm{L}^{-1}$}

To assess the optimum contact time requisite to reach the equilibrium state among the liquid phase (effluent) and the solid phase (biomass), this experiment was performed. Figure 6 shows the adsorption removal at different contact adsorption times for the two studied adsorbents. Both the ACDB and LFB adsorbents showed that the percentage removal increased with contact time, and after a certain time, no more dye could be removed from the aqueous solution. The maximum adsorption and equilibrium contact times occurred at $120 \mathrm{~min}$ with a percentage removal of $78.9 \%$ and $68.26 \%$. This is because there are limited adsorbent sites on the adsorbent and the rate of dye binding with biomass is more predominant during the initial stages; after a definite time, these were exhausted and the adsorption process reached a state of equilibrium and gradually decreased [43].

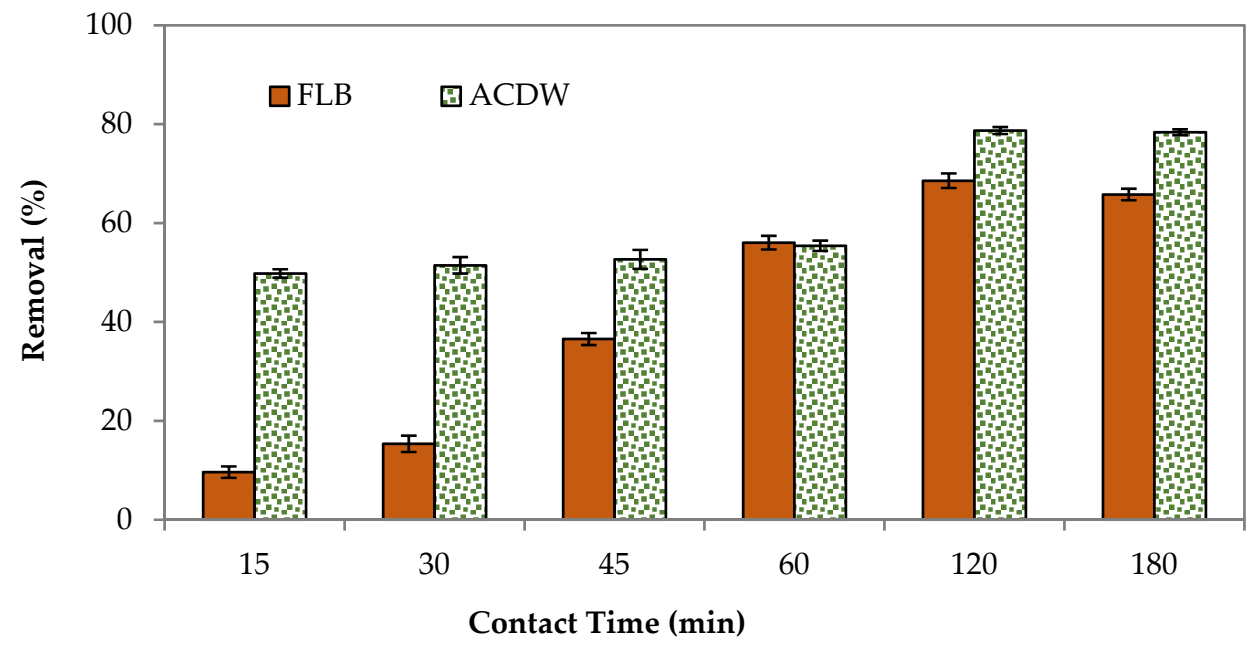

Figure 6. Influence of contact time on elimination efficiency of IV2R dye.

Vacant surface sites are available at the start of adsorption; nevertheless, once equilibrium is achieved, the remaining vacant sites are difficult to fill, most likely due to repulsive forces between molecules on the adsorbents in the bulk phase [44]. The dye equilibrium can be achieved in less than 15 min using two adsorbents. Still, to be on the safe side, a 120-min shaking time was chosen.

\subsection{4. $\mathrm{pH}$ Value}

The effectiveness with which pollutants are removed from aqueous solutions via adsorption is affected by the $\mathrm{pH}$ of the solution, as it affects the features of the adsorbent's surface charge as well as the form of the contaminants in solution [26]. The effect of initial $\mathrm{pH}$ on the percentage of treatment of IV2R using the ACDB and LFB adsorbents were estimated within the $\mathrm{pH}$ scope of 2-10 (Figure 7). The results confirmed that the adsorption uptake of LFB increased by the decreased $\mathrm{pH}$, recording the maximum uptake at $\mathrm{pH} 2$ with a percentage removal of $61.7 \%$. However, ACDB dye removal increased with increasing the $\mathrm{pH}$ up to 6 with the maximum removal of $70.5 \%$. According to the literature, the complex hetero polysaccharide and lipid elements of algae's cell wall matrix contain various functional groups such as amino, phosphate, hydroxyl, carboxyl, and other charged groups that are produced by their complex hetero polysaccharide and lipid constituents [45-48]. So, under acidic conditions, the $\mathrm{OH}, \mathrm{NH}_{2}, \mathrm{C}=\mathrm{O}$, and $\mathrm{COO}$ groups were protonated; as a result, the ACDB and LFB surface was positively charged. In addition, the ismate violet $2 \mathrm{R}$ - three sulphonate groups $\left(\mathrm{D}-\mathrm{SO}_{3} \mathrm{X}\right.$ ) were converted to anionic dye ions $\left(\mathrm{D}-\mathrm{SO}_{3}{ }^{-}\right)$that make it readily soluble in water, even in an extremely acidic medium [49]. Therefore, in this mechanism, electrostatic attraction happens between the anionic dye's sulphonate groups and the functional groups on the surface of ACDB and LFB. Additionally, the major adsorption capacity of adsorbent for IV2R adsorption occurs at $\mathrm{pH} 2-6$; at this 
$\mathrm{pH}$, the amino groups of the adsorbent are protonated, facilitating the adsorption of the negative charged dye, which leads to a decrease in the number of adsorption binding sites for the removal of dye [50]. However, the biomass will have a net positive charge at lower $\mathrm{pH}$ levels. It is expected that at acidic $\mathrm{pH}$ levels, nitrogen-containing functional groups in the biomass, such as amines or imadazoles, are predicted to be protonated as well. Higher uptakes at lower $\mathrm{pH}$ levels might be due to electrostatic interaction between negatively charged dye anions and the positively charged cell surface, as reported by [51,52]. While applying the alga Stoechospermum marginatum with acid orange II dye, a reduction in the percentage of dye removal was found with an increase in the $\mathrm{pH}$ of the dye solution [53], the adsorption of Reactive Red 120 using the alga Chara contraria [54], the removal of Remazol Brilliant Blue R from aqueous solution by the microalgae Scenedesmus quadricauda immobilized in alginate gel beads [55], and the removal of Lanaset Red $G$ dye from aqueous solution using the algal species Chara contraria [56].

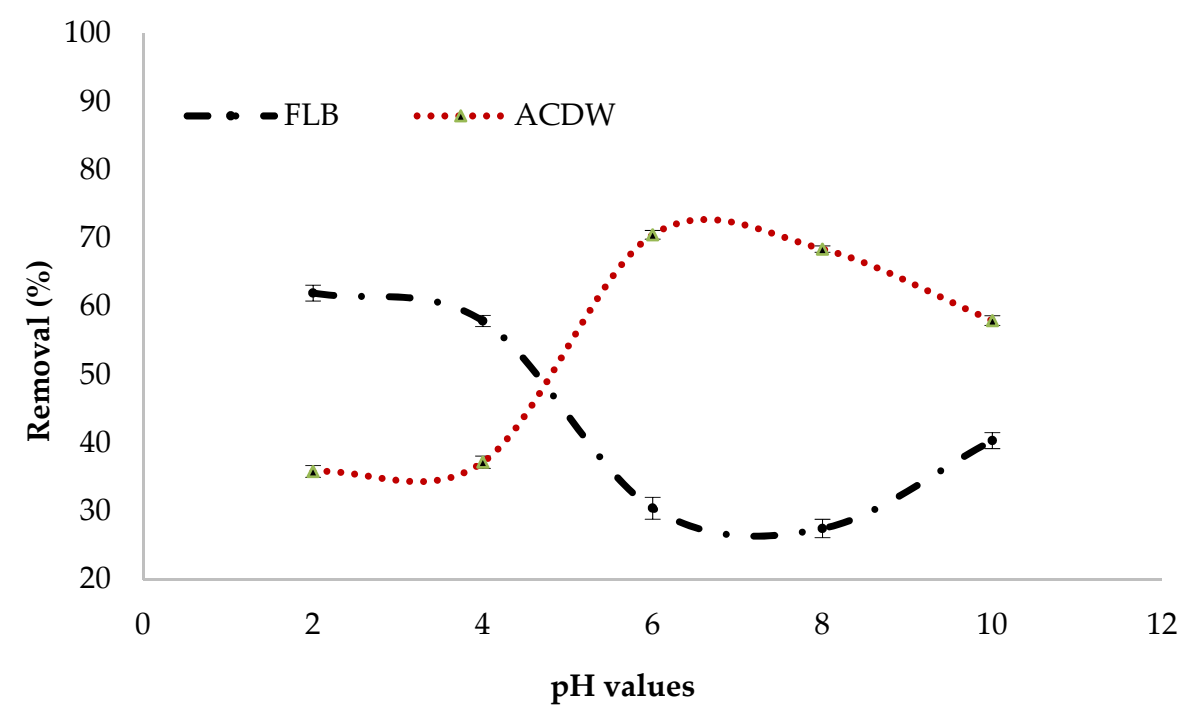

Figure 7. Influence of $\mathrm{pH}$ values on elimination efficiency of IV2R dye.

Mahmoud et al. [57] and Carneiro et al. [58] found that under low $\mathrm{pH}$ (acidic conditions), hydrogen ions $(\mathrm{H}+)$ interact with the amino group $\left(\mathrm{NH}_{2}\right)$ at carbon of the dye structure from $\mathrm{NH}_{3}$. This results in the configuration of the ionic form of the dye $\left[\mathrm{C}_{22} \mathrm{H}_{15} \mathrm{~N}_{4} \mathrm{O}_{11} \mathrm{~S}_{3} \mathrm{CuCl}\right]^{+}$, which has a positive charge on the $\mathrm{NH}_{3}$ group. This new ion is less stable. Therefore, as a consequence of the release of two hydrogen atoms from NH3+ in the form of hydrogen gas $\left(\mathrm{H}_{2}\right)$, the positive charge is transferred to carbon.

Nagendrappa [59] found that when the dye is exposed to alkali (high $\mathrm{pH}$ ), it removes one hydrogen ion $(\mathrm{H}+)$ from carbon, which interacts with a hydroxyl group $(\mathrm{OH}-)$ from the alkaline media to produce water $\left(\mathrm{H}_{2} \mathrm{O}\right)$. As a result, the neutral molecule is transformed into an ionic form with a negative charge at carbon. After that, electrons are transferred from the neighboring sulfonyl group to carbon, forming a structure with a sulfur carbon double bond $(\mathrm{S}=\mathrm{C})$ and negatively charged on the sulfonyl group's oxygen atom. The dye's change from a neutral component to an ionic form makes it easier to remove from solutions using a variety of ways.

\subsubsection{Adsorption Isotherm}

The Langmuir isotherm equation is very appropriate to describe the sorption on substance surfaces by homogeneous porosities. Values of the Langmuir constants $\mathrm{q}_{\max }$ and $\mathrm{b}$ obtained from the linear correlation are shown in Figure 8 and Table 3 with the corresponding correlation coefficients " $\mathrm{R}^{2}$ ". The fitting of investigational results with the Langmuir isotherm was confirmed by high $\mathrm{R}^{2}$ values. Additionally, the obtained data demonstrate that the Langmuir isotherm could be applied to provide the adsorption of 


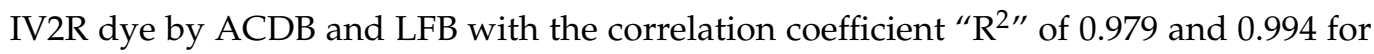
both ACDB and LFB adsorbents, respectively. This means that the Langmuir model could be applicable to the equilibrium data for the sorption of IV2R. Furthermore, the maximal uptake capacity $\left(\mathrm{q}_{\max }\right)$ is important to identify the adsorbent highest dye uptake. The maximal uptake capacity ( $\mathrm{q}_{\max }$ ) was 14.70 and $9.90 \mathrm{mg} \mathrm{g}^{-1}$ for ACDB and LFB adsorbents, respectively. The Langmuir constant (b), which reflects the heat of the sorption, was examined to be 0.12 and 0.023 for removal of IV2R for both ACDB and LFB adsorbents. The essential characteristics of the Langmuir model can be calculated via the constant of dimensionless so-called equilibrium parameter, $\left(\mathrm{R}_{\mathrm{L}}\right)$, defined through the following equation [60]:

$$
\mathrm{R}_{\mathrm{L}}=1 /\left(1+\mathrm{Ka} \times \mathrm{C}_{\mathrm{i}}\right)
$$

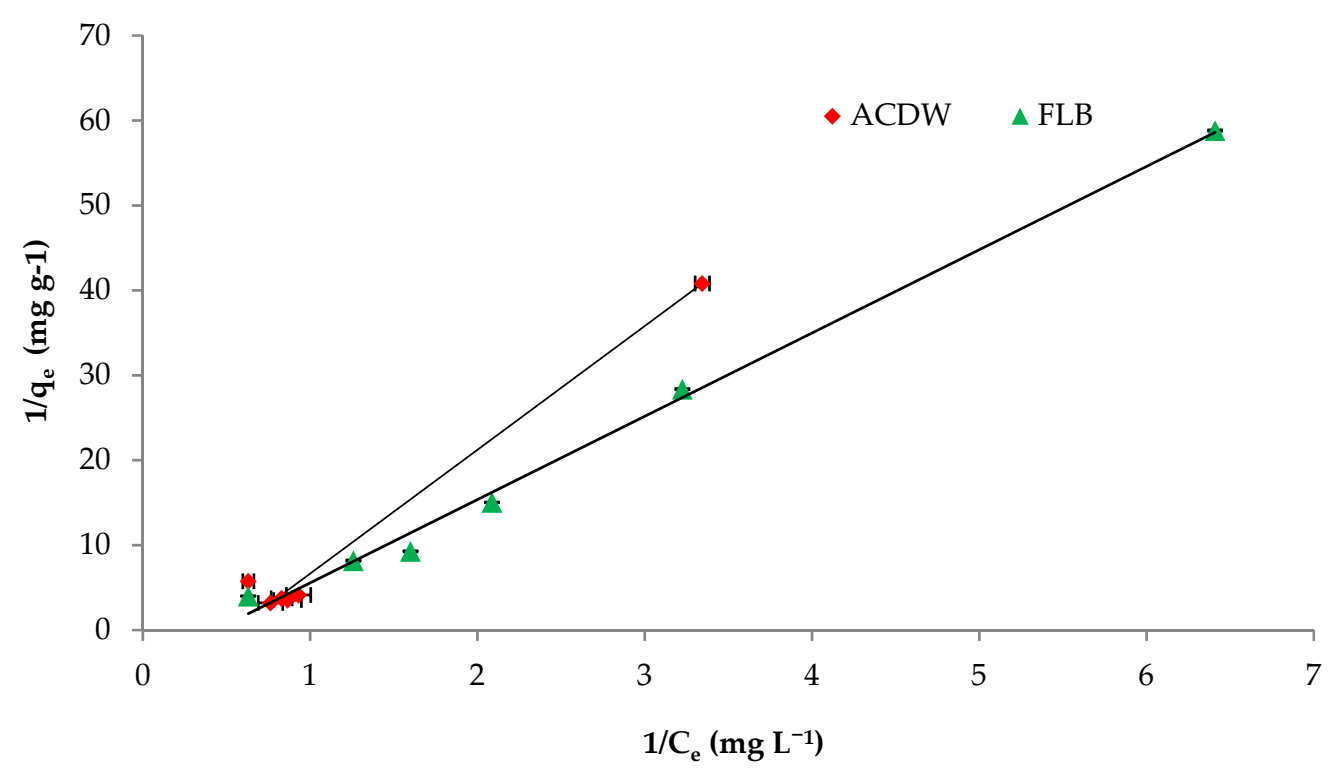

Figure 8. Langmuir isotherm plot for removal efficiency of IV2R dye.

Table 3. Values of isotherm constants for IV2R dye removal by ACDB and LFB.

\begin{tabular}{cccc}
\hline \multirow{2}{*}{ Isotherm Model } & Isotherm & \multicolumn{2}{c}{ Values } \\
& Parameter & ACDB & LFB \\
\cline { 2 - 4 } & $\mathrm{n}$ & 0.668 & 0.837 \\
Freundlich & $\mathrm{K}_{\mathrm{F}}$ & 5.766 & 6.3 \\
& $\mathrm{R}^{2}$ & 0.856 & 0.988 \\
\hline \multirow{3}{*}{ Langmuir } & $\mathrm{q}_{\max }\left(\mathrm{mg} \mathrm{g}^{-1}\right)$ & 14.70 & 9.90 \\
& $\mathrm{~b}$ & 0.129 & 0.023 \\
& $\mathrm{R}^{2}$ & 0.979 & 0.994 \\
& $\mathrm{R}_{\mathrm{L}}$ & 0.856 & 0.988 \\
\hline \multirow{3}{*}{ Tempkin } & $\mathrm{A}_{\mathrm{T}}$ & 11.42 & 5.36 \\
& $\mathrm{~B}_{\mathrm{T}}$ & 0.143 & 0.098 \\
& $\mathrm{~b}_{\mathrm{T}}$ & 0.195 & 0.284 \\
& $\mathrm{R}^{2}$ & 0.67 & 0.881 \\
\hline \multirow{2}{*}{ Halsey } & $1 / \mathrm{n}$ & 1.49 & 1.19 \\
& $\mathrm{~K}$ & 1.75 & 1.84 \\
& $\mathrm{R}^{2}$ & 0.856 & 0.989 \\
\hline
\end{tabular}

$\mathrm{R}_{\mathrm{L}}$ can serve to demonstrate the affinity among the sorbate (dye ions) and sorbent (ACDB and LFB) by separation factor or/and dimensionless equilibrium factor and $\mathrm{Ka}$ is the constant of Langmuir. The results of separation factor $\mathrm{R}_{\mathrm{L}}$ gives important information 
around the nature of adsorption. From this study, the average $\mathrm{R}_{\mathrm{L}}$ was obtained to be 0.877 and 0.994 for concentration of 10-100 $\mathrm{mg} \mathrm{L}^{-1}$ of IV2R dyes for ACDB and LFB, respectively; as displayed in Table 3, the value data of $R_{\mathrm{L}}$ indicated the type of Langmuir equation to be favorable $\left(0<R_{L}<1\right)$, irreversible $\left(R_{L}=0\right)$, unfavorable $\left(R_{L}>1\right)$, and linear $\left(R_{L}=1\right)$ [35]. They are in the scope from $0-1$, which describes the favorable adsorption process.

Freundlich isotherm gave a better fit for IV2R with a higher correlation coefficient of 0.988 for LFB adsorbent, while this model gave a lower fit by ACDB adsorbent with correlation coefficient 0.856 as shown in Figure 9 and Table 3. On the other hand, the Freundlich constant " $\mathrm{K}_{\mathrm{f}}$ " displays the sorption capacity on heterogeneous sites with nonuniform spreading of the energy level and can work as indicators for the maximum adsorption capacity of the dye cation from the adsorbent. The value of the " $n$ " parameter of the Freundlich equation can act as an indicator on the favorability of adsorption and shows the intensity among dyes and biomass. The " $\mathrm{K}_{\mathrm{f}}$ " values were 5.76 and 6.3 for both ACDB and LFB adsorbents, respectively. Moreover, a strong bond is existent among two adsorbents, as shown via the data of $1 / \mathrm{n}$, "called the heterogeneity factor", describing the deviation from the linearity of adsorption as follows: when $1 / \mathrm{n}$ is below 1 , chemical adsorption happens, and this demonstrates an ordinary Langmuir isotherm; however, when $1 / \mathrm{n}$ is further than 1 , cooperative adsorption takes place, and the sorption process is more favorable physically and comprises strong interactions between the particles of the dye solution; when $1 / \mathrm{n}$ is equivalent to 1 , the adsorption is linear, and the dye particle concentration does not influence the division between the two stages [34]. In this study, the values of factor " $1 / \mathrm{n}$ " are less than 1 for ACDB and LFB adsorbents; the values show a physical adsorption method on an external surface with this equation to be favorable.

$\log \operatorname{Ce}\left(\mathrm{mg} \mathrm{L}^{-1}\right)$

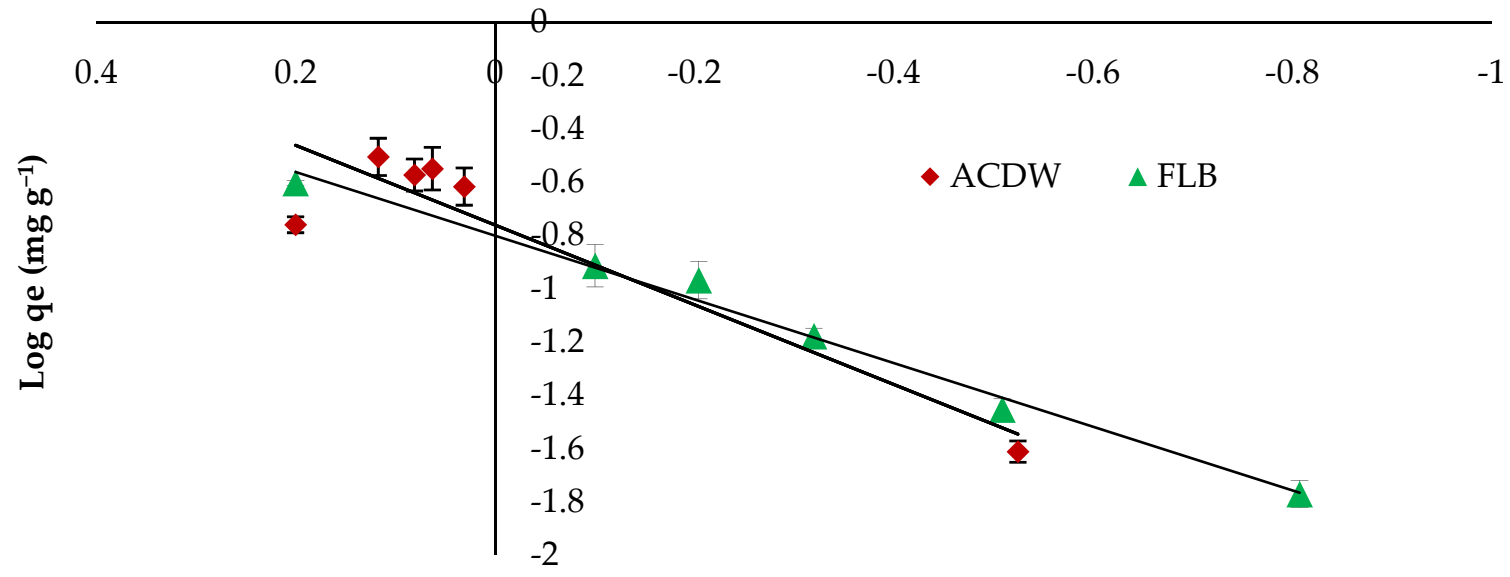

Figure 9. Freundlich isotherm plot for removal efficiency of IV2R dye.

Tempkin isotherm shows the influence of some indirect interactions between adsorbate molecules and suggests a linear reduction in the heat of the sorption process of the particles in each layer, owing to these interactions [61]. The value of the regression coefficient (R2+) was found to be 0.67 and 0.881 for both ACDB and LFB adsorbents, respectively (Figure 10), which indicate that this model is not favorable for the removal of IV2R dye. The Tempkin constants A and B were presented in Table 3.

The Halsey isotherm is appropriate for multilayer sorption process, and the fitting of the Halsey model could be useful to heterologous solids [62]. The plots of Ln $\mathrm{q}_{\mathrm{e}}$ against the $\mathrm{Ln} \mathrm{C}_{\mathrm{e}}$ Halsey adsorption isotherms are shown in Figure 11. The parameters obtained for the Halsey isotherm were fitted with ACDB and LFB adsorbents, with high regression correlation coefficients ranging between 0.856 and 0.989 . The Halsey isotherm parameters of $\mathrm{K}$ and $\mathrm{n}$ are presented in Table 3. 


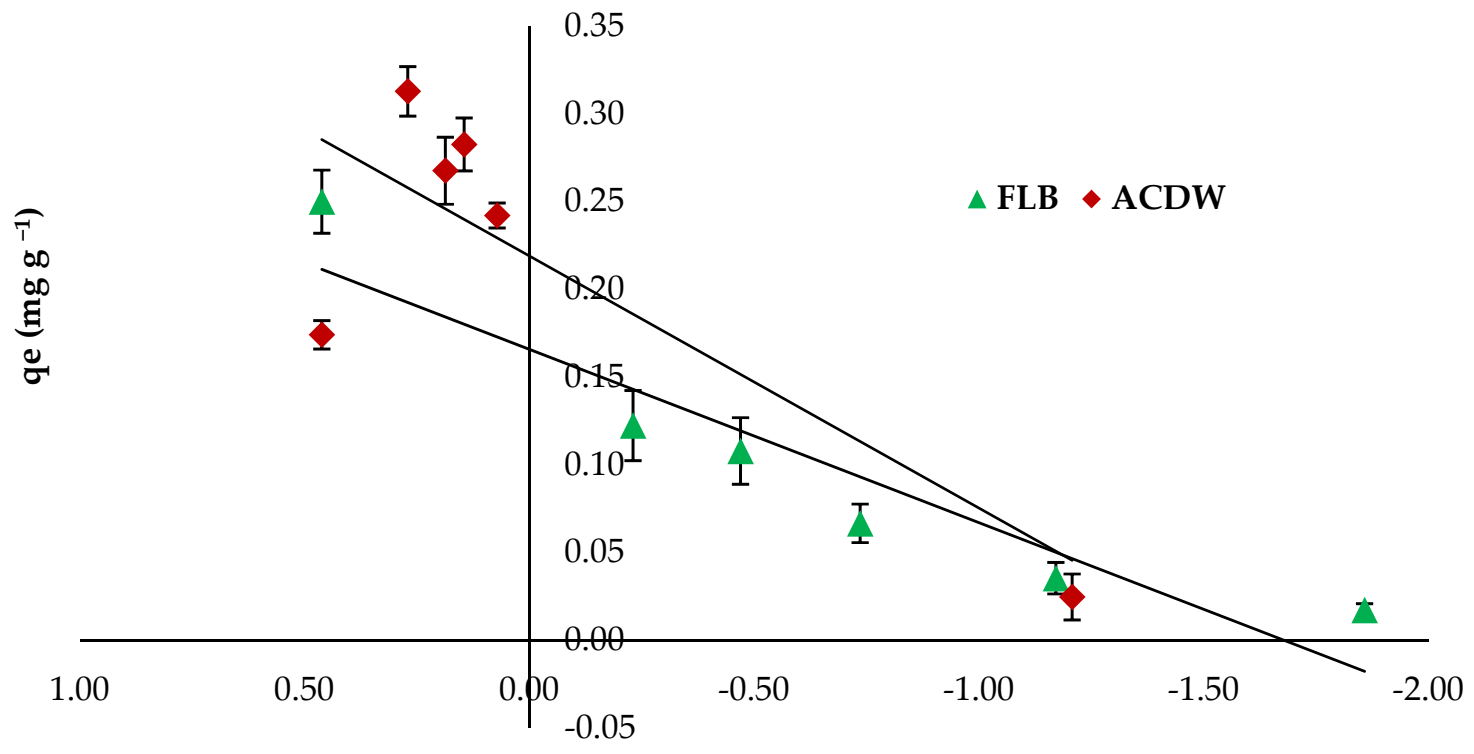

$\operatorname{Ln}(\mathrm{Ce})\left(\mathrm{mg} \mathrm{L}^{-1}\right)$

Figure 10. Tempkin isotherm plot for removal efficiency of IV2R dye.

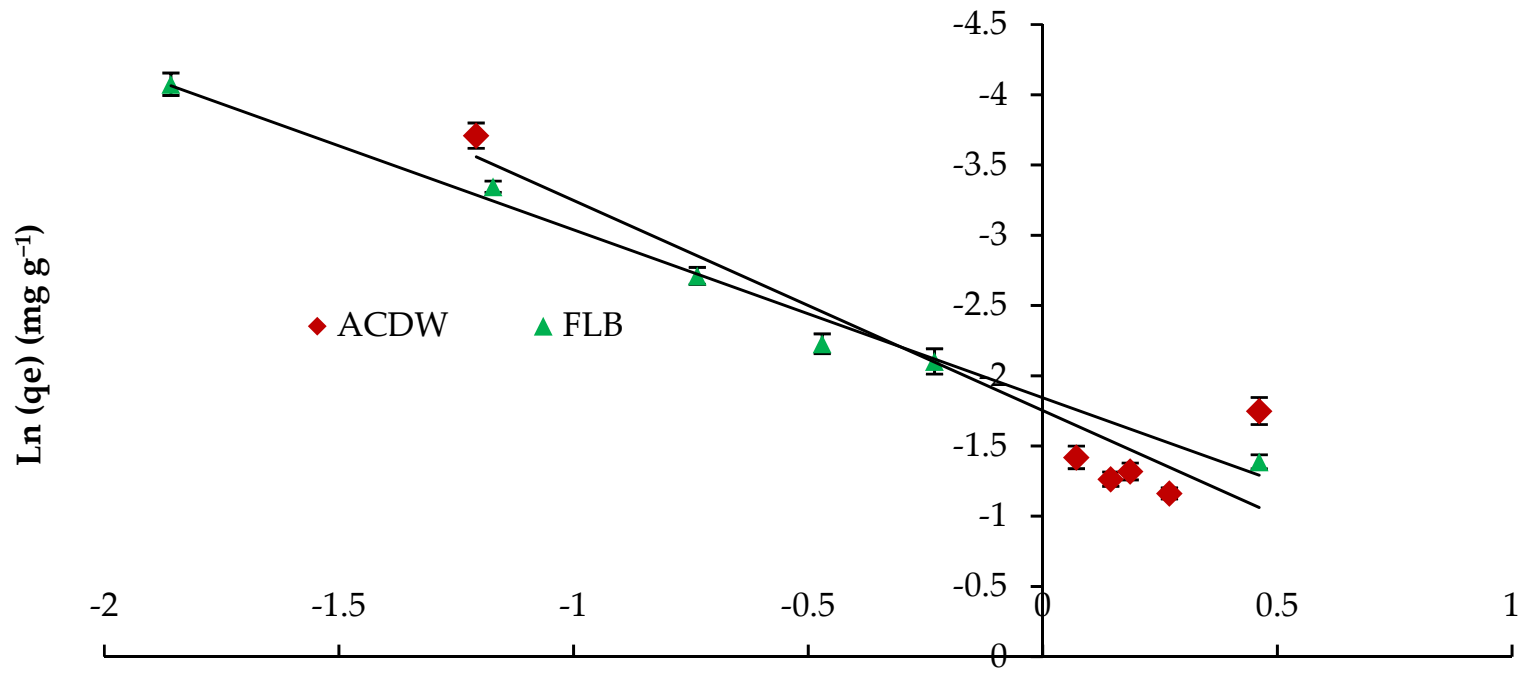

$\operatorname{Ln}(\mathrm{Ce})\left(\mathrm{mg} \mathrm{L}^{-1}\right)$

Figure 11. Halsey model plot for removal efficiency of IV2R dye.

The kinetics study of adsorbate uptake is an important parameter for selecting the best operating conditions to know the dynamics of the sorption reaction and for design purposes in expressions of the order of the rate constant. The kinetics values achieved from the sorption process of IV2R dye onto ACDB and LFB was examined by using three communal kinetic models, which are the pseudo-first- and second-order kinetic models in addition intraparticle diffusion model. Furthermore, the most appropriate model was chosen depending on the regression correlation coefficient $\left(R^{2}\right)$ to determine how well the predicted data from a forecast model matches with the investigational data. The pseudo-first order was applied to explain the sorption rate depending on the capacity of adsorption. This model posits that the ratio of occupation of adsorption sites in the surface is proportional to the numeral of unoccupied sites. Table 4 provided the result data of $\mathrm{K}_{1}$, investigational and calculated data of $\mathrm{q}_{\mathrm{e}}$, in addition to the correlation coefficients value for the pseudo-first kinetic plots. The theoretical values of $\mathrm{q}_{\mathrm{e}}$ are not in line with the 
experimental data acquired. This suggests a poor fit amongst the kinetics data and the pseudo-first order equation. Additionally, it was presented that the pseudo-first order were ruled out as a result of their correlation coefficients for the current experimental results being small $\left(R^{2}=0.113\right.$ and 0.716$)$ for ACDB and LFB adsorbents, respectively. This suggests that this adsorption system is not an ideal first-order reaction. It was observed from Figure 12 and Table 4 that the pseudo-second order kinetic fit well with higher correlation coefficients $\left(\mathrm{R}^{2}=0.980\right.$ and 0.987 for ACDB and LFB adsorbents, respectively). Moreover, it was clear that the result value of $k_{2}$ parameter was greater than the corresponding $k 1$ parameter value. This is for the reason that the pseudo-second-order presumes that the adsorption rate is relative to the square of a number of unoccupied sites, as reported by Gupta et al. [63].

Table 4. Comparison of the kinetic model for IV2R dyes from ACDB and LFB.

\begin{tabular}{|c|c|c|c|c|c|c|c|c|c|}
\hline \multirow{2}{*}{$\begin{array}{c}\text { Model } \\
\text { Parameters }\end{array}$} & \multicolumn{3}{|c|}{ 1st-Order Kinetic Model } & \multicolumn{3}{|c|}{ 2nd-Order Kinetic Model } & \multicolumn{3}{|c|}{ Intraparticle Diffusion Model } \\
\hline & $\begin{array}{l}\mathrm{qe}_{\mathrm{e}}(\mathrm{calc} .) \\
\left(\mathrm{mg} \mathrm{g}^{-1}\right)\end{array}$ & $\begin{array}{c}\mathrm{k}_{1} \\
\left(1 \mathrm{~min}^{-1}\right)\end{array}$ & $\mathbf{R}^{2}$ & $\begin{array}{l}\mathrm{qe}_{\mathrm{e}}(\text { calc. }) \\
\left(\mathrm{mg} \mathrm{g}^{-1}\right)\end{array}$ & $\begin{array}{c}\mathrm{k}_{2} \\
\left(\mathrm{mg} \mathrm{g}^{-1}\right. \\
\left.\min ^{-1}\right)\end{array}$ & $\mathbf{R}^{2}$ & $\begin{array}{c}\mathrm{K}_{\mathrm{dif}} \\
(\mathrm{mg} g \\
\left.\text { in }^{-0.5}\right)\end{array}$ & $\mathrm{C}$ & $\mathbf{R}^{2}$ \\
\hline ACDB & 13.18 & 0.012 & 0.11 & 0.105 & 0.426 & 0.980 & 0.0078 & 0.123 & 0.825 \\
\hline LFB & 1.018 & $\begin{array}{c}9.21 \times \\
10^{-4}\end{array}$ & 0.716 & 0.036 & 1.688 & 0.987 & 0.0043 & 0.039 & 0.891 \\
\hline
\end{tabular}

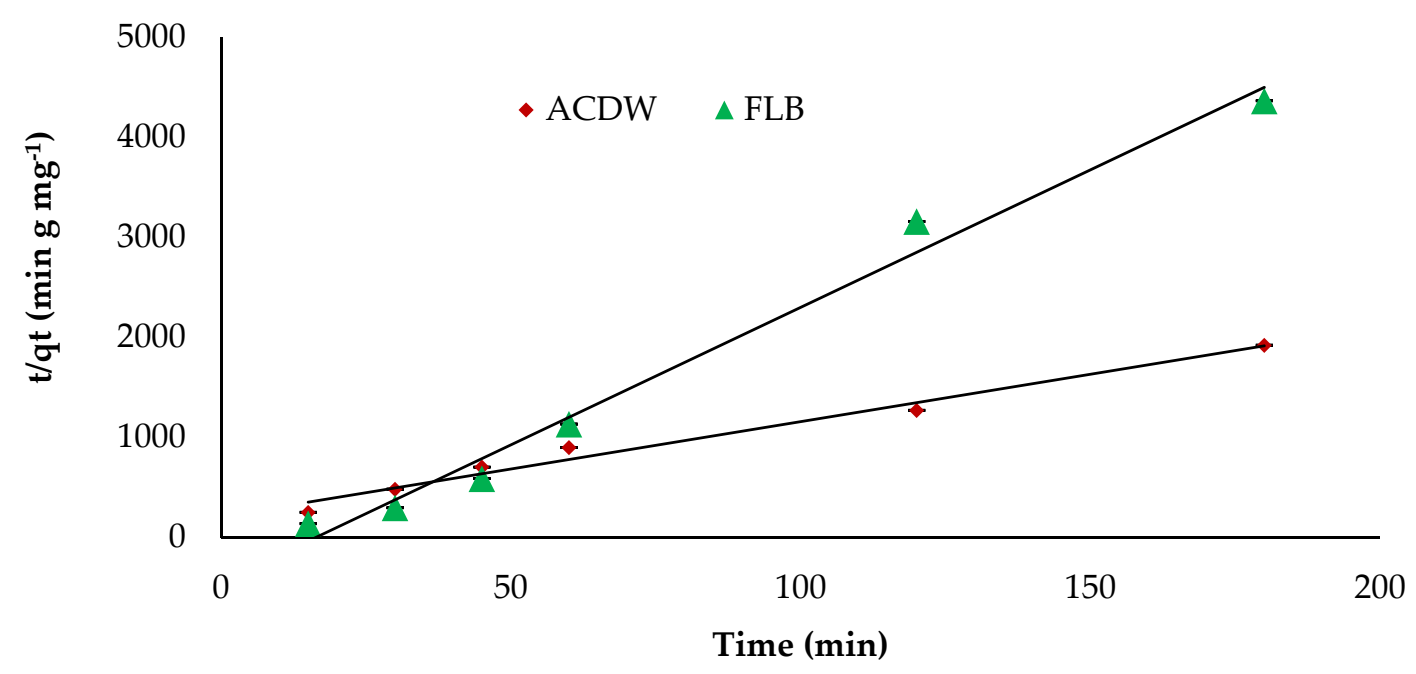

Figure 12. Pseudo-second kinetics of IV2R dyes onto ACDB and LFB.

The figures of $q_{t}$ inverse $t^{0.5}$ explain the intraparticle diffusion model, which may represent a numerous-linearity correlation, which shows that two or more stages happen through the adsorption method (Figure 13). Moreover, the rate constant $\mathrm{K}_{\mathrm{dif}}$ directly estimated from the slope and the intercept is $C$, as recorded in Table 4 . The values' $C$ factors offer information around the thickness of the border layer, as the resistance to the exterior mass transfer rises as the intercept increases. Furthermore, the low linearity of the plots demonstrated intra-particle diffusion in the uptake of IV2R dyes by ACDB and LFB with a low correlation coefficient $R^{2}$. 


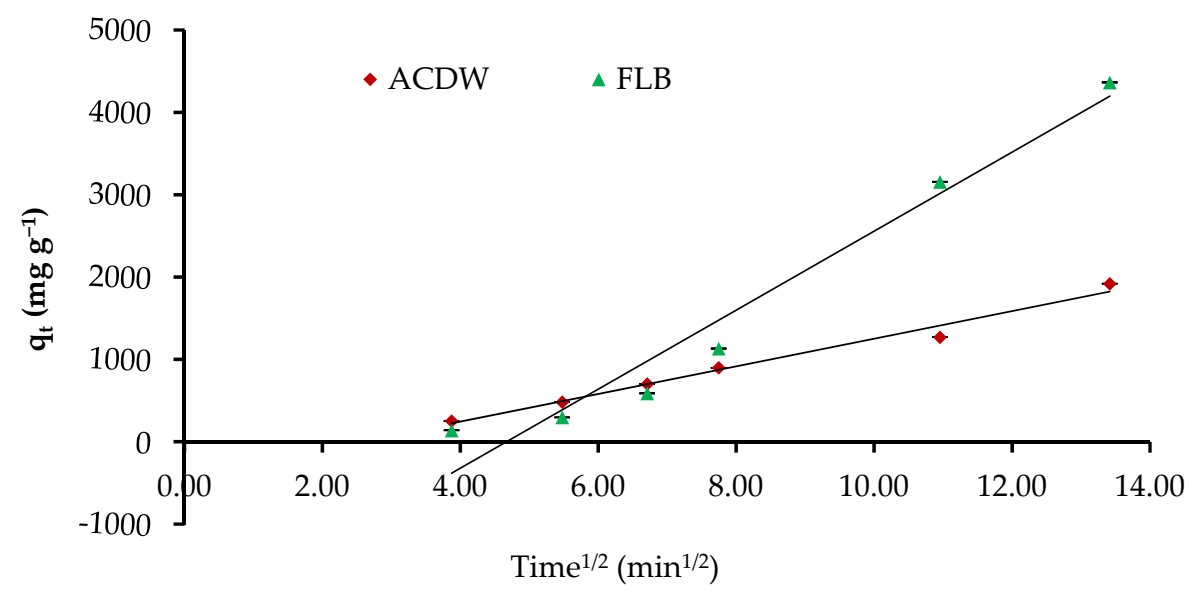

Figure 13. Intraparticle diffusion kinetics of IV2R dyes onto ACDB and LFB.

\subsubsection{Applicability on Actual Wastewater}

To evaluate the validity of the uses of ACDB and LFB as adsorbents, real wastewater samples were collected to examine for removal of IV2R by two adsorbents studies under optimization conditions. The application of Spirulina to eliminate IV2R from wastewater was carried out under optimization conditions. Table 5 shows that a near 75.7 and $61 \%$ removal of IV2R dye from real wastewater was detected for ACDB and LFB, respectively, while the percentage elimination of IV2R dye from aqueous solution was 83 and $56.4 \%$. The results confirmed that the percentage removal of IV2R through two adsorbents from aqueous solution was not influenced by replacing the distilled water by real wastewater in LFB, while the highest removal for ACDB was significantly altered by changing of the kind of water, of which deionized water exhibited the lowest influence on the adsorption method. Conversely, the real wastewater effluents can comprise very high concentrations of interfering ions from numerous pollutants that will have a significant influence on the elimination efficiency of IV2R dye.

Table 5. Percentage of removal for IV2R dyes by using ACDB and LFB in a different water sample.

\begin{tabular}{ccc}
\hline \multirow{2}{*}{ Types of Water } & \multicolumn{3}{c}{ IV2R Removal (\%) } \\
\cline { 2 - 3 } & ACDB & LFB \\
\hline Industrial wastewater & 75.79 & 61.11 \\
Distilled water & 83.33 & 56.41 \\
\hline
\end{tabular}

\subsection{Rotifer Bioassay}

Marine Rotifera, B. plicatilis, is a zooplankton that is extensively utilized as live feed for larvae in aquatic hatcheries [22,64]. Interestingly, rotifer (Brachionus plicatilis) is one of the most extensively aquatic animals utilized in environmental toxicity studies due to it being easy to keep in the laboratory and that it can be preserved at high population densities in minor volumes, has a short life cycle, and that it is a good indicator of heavy metal pollution [65]. In the current study, Figure 14A-D shows the rotifer population, rotifer mortality, female carry eggs population, and the mortality of female carry eggs, respectively.

At all levels, the ACDB and LFB loaded by IV2R resulted in lower rotifer B. plicatilis population (Figure 14A) and the number of female carry eggs (Figure 14B), when compared to the traditional ACDB and LFB (controls) at the same levels. On the contrary, ACDB and LFB loaded by IV2R resulted in higher rotifer total mortality (Figure 14C) and female carry eggs mortality (Figure 14D), when compared to the traditional ACDB and LFB at the same levels. In the case of ACDB and LFB loaded by IV2R, the level 0.02 LFB has achieved the highest rotifer population, followed by the level of 0.02 ACDB. The levels $0.02 \mathrm{LFB}$ and $0.2 \mathrm{ACDB}$ achieved the highest number of female carry eggs. The higher mortality of total rotifer number and/or female carry eggs mortality were observed in higher levels 
of ACDB and LFB loaded by IV2R, compared to those of lower levels of ACDB and LFB loaded by IV2R. These results concluded that marine rotifer B. plicatilis was sensitive to dye IV2R attributed to reduced rotifer population and female carry eggs and increased rotifer mortality, in general. Due to the attendance of metal ions of dyes from organic dyes in the marine environment influencing the marine life, which can result in the death of zooplankton or slow growth organisms that, based on zooplankton for food and also dyes, can decrease zooplankton nutrition supplies of larval fish [23].
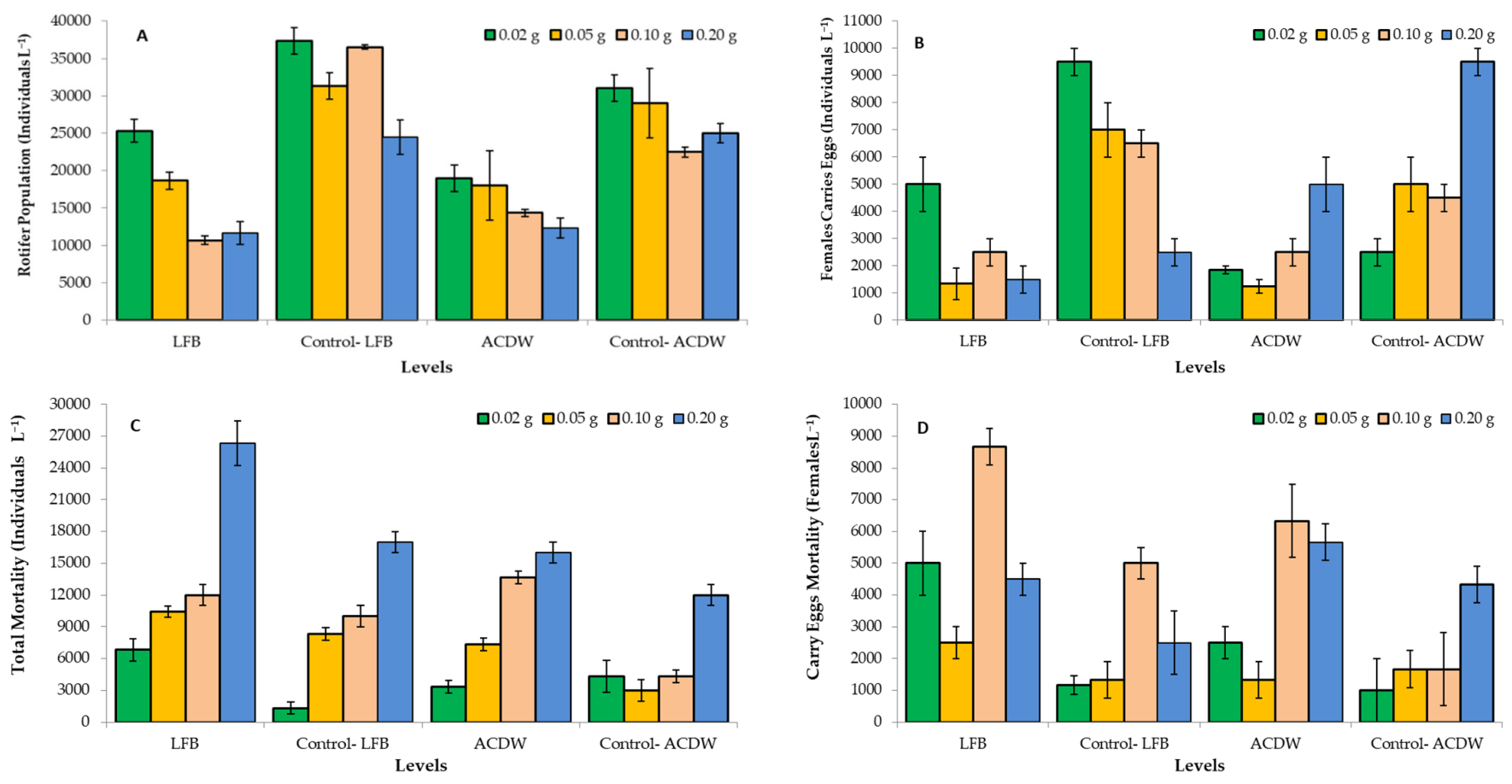

Figure 14. Effect of different levels of Arthrospira platensis NIOF17/003 complete dry weight (ACDB) and free lipid (LFB) which was loaded by dye (Ismate violet 2R, IV2R) removed from industrial textile effluents, on rotifer Brachionus plicatilis population (A), female carry eggs population (B), and total rotifer mortality (C), and female carry eggs mortality (D).

\section{Conclusions}

The current work investigated the efficiency of ACDB and LFB in bioremediation of dye (IV2R) from industrial textile effluents. The potential of the ACDB and LFB loaded by IV2R as a feed for rotifer B. plicatilis throughout the bioassay test was also investigated. The adsorption of IV2R dye into Arthrospira platensis NIOF17/003 was prepared and the given results showed that the adsorption process increased with increasing ACDB and LFB dose, contact time (120 min), initial IV2R concentration $\left(10 \mathrm{mg} \mathrm{L}^{-1}\right)$, and acidity $\mathrm{pH}$ ( 2 and 6, respectively), giving it a relatively large affinity with respect to ACDB and LFB. Physical and chemical characteristics of ACDB and LFB were obtained by FTIR, SEM, and Raman spectroscopy. Moreover, Freundlich, Langmuir, Tempkin, and Halsey adsorption models were conducted to describe the equilibrium isotherms while the isotherm constants were determined. By comparing the correlation coefficients obtained for the studied isotherm models, all isotherm models fit the experimental data reasonably well, except Tempkin models for LFB. In addition, Langmuir was fit for ACDB at optimum condition with a regression co-efficient higher than 0.9. However, the value of $R_{L}$ in the case of Langmuir isotherms lies between 0 and 1 , indicating convenient adsorption. In addition, the three models (pseudo-first order, pseudo-second order, and intra-particle diffusion) were conducted to find the suitable kinetic model for adsorption techniques. It has been found that the sorption kinetics of IV2R has a poor fit with the pseudo-first-order kinetic equation, while they have preferably obeyed the second-order kinetic models which provide a higher correlation coefficient. Furthermore, the intra-particle diffusion was also 
examined, and it was revealed that the adsorption process is regulated by the film diffusion with a regression co-efficient higher than 0.82 and 0.89 for ACDB and LFB, respectively. For the removal of industrial textile effluents, the ACDB and LFB adsorbents offered a good ability to eliminate $75.7 \%$ and $61.11 \%$, respectively, of a dye solution. On the other hand, as a by-product, the ACDB and LFB loaded by IV2R up to a level of $0.02 \mathrm{~g}$ could be used as feed for marine rotifer B. plicatilis. Furthermore, the findings indicated that adsorbent may be successfully utilized to extract IV2R dye from aqueous solutions and wastewater at a cheap cost and with minimal environmental impact.

Author Contributions: A.E.A., A.M.M.H., M.A., A.E.-F.A., and A.T.M.; methodology, M.A., A.E.A., A.M.M.H., M.A.A.-S., Z.Z.S., and A.T.M.; software, A.M.M.H., A.E.A., M.A., and M.A.A.-S. Z.Z.S.; formal analysis, M.A., A.E.A., A.M.M.H., Z.Z.S., and A.E.-F.A.; investigation, A.E.A., M.A., and A.M.M.H.; resources, M.A., A.E.A., K.M.A., D.A., and A.T.M.; data curation, A.E.A., M.A., A.M.M.H., D.A., A.E.-F.A., Z.Z.S., and A.T.M.; writing—original draft preparation, A.E.A., M.A., and Z.Z.S.; writing-review and editing, A.E.A., M.A., and A.T.M.; visualization, A.E.A., M.A., A.M.M.H., and A.T.M.; supervision, M.A., A.M.M.H., K.M.A., and A.T.M.; project administration, A.E.A.; funding acquisition, K.M.A. and D.A. All authors have read and agreed to the published version of the manuscript.

Funding: The authors appreciate Taif University Researchers Supporting Project number TURSP2020/267, Taif University, Taif, Saudi Arabia.

Institutional Review Board Statement: Not applicable.

Informed Consent Statement: Not applicable.

Data Availability Statement: All relevant data are within the paper, and are available from the corresponding author.

Acknowledgments: The authors appreciated Taif University Researchers Supporting Project number TURSP-2020/267, Taif University, Taif, Saudi Arabia.

Conflicts of Interest: The authors declare no conflict of interest.

\section{References}

1. Heneash, A.M.; Alprol, A.E.; Abd El-Hamid, H.T.; Khater, M.; El Damhogy, K.A. Assessment of water pollution induced by anthropogenic activities on zooplankton community in Mariout Lake using statistical simulation. Arab. J. Geosci. 2021, 14, 641. [CrossRef]

2. Calvete, T.; Lima, E.C.; Cardoso, N.F.; Dias, S.L.P.; Pavan, F.A. Application of carbon adsorbents prepared from the Brazilian pine-fruit-shell for the removal of Procion Red MX 3B from aqueous solution-Kinetic, equilibrium, and thermodynamic studies. Chem. Eng. J. 2009, 155, 627-636. [CrossRef]

3. Cardoso, N.F.; Pinto, R.B.; Lima, E.C.; Calvete, T.; Amavisca, C.V.; Royer, B.; Cunha, M.L.; Fernandes, T.H.M.; Pinto, I.S. Removal of remazol black B textile dye from aqueous solution by adsorption. Desalination 2011, 269, 92-103. [CrossRef]

4. Mondal, P.; Baksi, S.; Bose, D. Study of Environmental Issues in Textile Industries and Recent Wastewater Treatment Technology. World Sci. News 2017, 61, 98-109.

5. National Environmental Agency. Allowable Limits for Trade Effluent Discharge to Watercourse or Controlled Watercourse. Available online: https:/ / www.nea.gov.sg/our-services/pollution-control/water-quality/allowable-limits-for-trade-effluentdischarge-to-watercourse-or-controlled-watercourse (accessed on 25 July 2021).

6. Kannan, R.R.; Rajasimman, M.; Rajamohan, N.; Sivaprakash, B. Brown marine algae Turbinaria conoides as biosorpent for Malachite green removal: Equilibrium and kinetic modelling. Front. Environ. Sci. Engin. China 2010, 4, 16-122.

7. Min, S.K.; Kim, W.Y.; Cho, Y.; Kim, K.S. Fast DNA sequencing with a graphene-based nanochannel device. Nat. Nanotechnol. 2011, 6, 162-165. [CrossRef]

8. Abualnaja, K.M.; Alprol, A.E.; Abu-Saied, M.A.; Mansour, A.T.; Ashour, M. Studying the Adsorptive Behavior of Poly (Acrylonitrile-co-Styrene) and Carbon Nanotubes (Nanocomposites) Impregnated with Adsorbent Materials towards Methyl Orange Dye. Nanomaterials 2021, 11, 1144. [CrossRef]

9. Dotto, G.L.; Lima, E.C.; Pinto, L.A.A. Biosorption of food dyes onto Spirulina platensis nanoparticles: Equilibrium isotherm and thermodynamic analysis. Bioresour. Technol. 2012, 103, 123-130. [CrossRef]

10. Sharawy, Z.Z.; Ashour, M.; Abbas, E.; Ashry, O.; Helal, M.; Nazmi, H.; Kelany, M.; Kamel, A.; Hassaan, M.; Rossi, W.; et al. Effects of dietary marine microalgae, Tetraselmis suecica, on production, gene expression, protein markers and bacterial count of Pacific white shrimp Litopenaeus vannamei. Aquac. Res. 2020, 51, 2216-2228. [CrossRef] 
11. Ashour, M.; Mabrouk, M.; Abo-Taleb, H.A.; Sharawy, Z.Z.; Ayoub, H.F.; Van Doan, H.; Davies, S.J.; El-Haroun, E.; Goda, A.A. A liquid seaweed extract $(\mathrm{TAM} \AA)$ improves aqueous rearing environment, diversity of zooplankton community, whilst enhancing growth and immune response of Nile tilapia, Oreochromis niloticus, challenged by Aeromonas hydrophila. Aquaculture 2021, 543, 736915. [CrossRef]

12. Hassan, S.M.; Ashour, M.; Soliman, A.A.F.; Hassanien, H.A.; Alsanie, W.F.; Gaber, A.; Elshobary, M.E. The Potential of a New Commercial Seaweed Extract in Stimulating Morpho-Agronomic and Bioactive Properties of Eruca vesicaria (L.) Cav. Sustainability 2021, 13, 4485. [CrossRef]

13. El-Shenody, R.A.; Ashour, M.; Ghobara, M.M.E. Evaluating the chemical composition and antioxidant activity of three Egyptian seaweeds: Dictyota dichotoma, Turbinaria decurrens, and Laurencia obtusa. Braz. J. Food Technol. 2019, 22. [CrossRef]

14. Shao, W.; Ebaid, R.; El-Sheekh, M.; Abomohra, A.; Eladel, H. Pharmaceutical applications and consequent environmental impacts of Spirulina (Arthrospira): An overview. Grasas Aceites 2019, 70, 292. [CrossRef]

15. Elshobary, M.E.; El-Shenody, R.A.; Ashour, M.; Zabed, H.M.; Qi, X. Antimicrobial and antioxidant characterization of bioactive components from Chlorococcum minutum. Food Biosci. 2020, 35, 100567. [CrossRef]

16. Barra, L.; Chandrasekaran, R.; Corato, F.; Brunet, C. The challenge of ecophysiological biodiversity for biotechnological applications of marine microalgae. Mar. Drugs 2014, 12, 1641-1675. [CrossRef] [PubMed]

17. Han, S.; Jin, W.; Chen, Y.; Tu, R.; Abomohra, A.E.-F. Enhancement of lipid production of Chlorella pyrenoidosa cultivated in municipal wastewater by magnetic treatment. Appl. Biochem. Biotechnol. 2016, 180, 1043-1055. [CrossRef] [PubMed]

18. Abomohra, A.E.-F.; Eladel, H.; El-Esawi, M.; Wang, S.; Wang, Q.; He, Z.; Feng, Y.; Shang, H.; Hanelt, D. Effect of lipid-free microalgal biomass and waste glycerol on growth and lipid production of Scenedesmus obliquus: Innovative waste recycling for extraordinary lipid production. Bioresour. Technol. 2018, 249, 992-999. [CrossRef] [PubMed]

19. Ashour, M.; Elshobary, M.E.; El-Shenody, R.; Kamil, A.W.; Abomohra, A.E.F. Evaluation of a native oleaginous marine microalga Nannochloropsis oceanica for dual use in biodiesel production and aquaculture feed. Biomass Bioenergy 2019, 120, $439-447$. [CrossRef]

20. Abomohra, A.E.-F.; Sheikh, H.M.A.; El-Naggar, A.H.; Wang, Q. Microwave vacuum co-pyrolysis of waste plastic and seaweeds for enhanced crude bio-oil recovery: Experimental and feasibility study towards industrialization. Renew. Sustain. Energy Rev. 2021, 149, 111335. [CrossRef]

21. Abomohra, A.E.-F.; Zheng, X.; Wang, Q.; Huang, J.; Ebaid, R. Enhancement of biodiesel yield and characteristics through in-situ solvo-thermal co-transesterification of wet microalgae with spent coffee grounds. Bioresour. Technol. 2021, 323, 124640. [CrossRef] [PubMed]

22. Zaki, M.A.; Ashour, M.; Heneash, A.M.M.; Mabrouk, M.M.; Alprol, A.E.; Khairy, H.M.; Nour, A.M.; Mansour, A.T.; Hassanien, H.A.; Gaber, A. Potential Applications of Native Cyanobacterium Isolate (Arthrospira platensis NIOF17/003) for Biodiesel Production and Utilization of Its Byproduct in Marine Rotifer (Brachionus plicatilis) Production. Sustainability 2021, $13,1769$. [CrossRef]

23. FAO. The State of World Fisheries and Aquaculture 2018-Meeting the Sustainable Development Goals; FAO: Rome, Italy, $2018 ;$ pp. 1-277.

24. Heneash, A.M.M.; Alprol, A.E. Monitoring of Water Quality and Zooplankton Community in Presence of Different Dietary Levels of Commercial Wood Charcoal of Red Tilapia. J. Aqua. Res. Dev. 2020, 11, 592. [CrossRef]

25. Abomohra, A.E.-F.; El-Sheekh, M.; Hanelt, D. Pilot cultivation of the chlorophyte microalga Scenedesmus obliquus as a promising feedstock for biofuel. Biomass Bioenergy 2014, 64, 237-244. [CrossRef]

26. Ghoneim, M.M.; El-Desoky, H.S.; El-Moselhy, K.M.; Amer, A.; Abou El-Naga, E.H.; Mohamedein, L.I.; Al-Prol, A.E. Removal of cadmium from aqueous solution using marine green algae, Ulva lactuca. Egypt. J. Aquat. Res. 2014, 40, 235-242. [CrossRef]

27. Abd El-Mohdy, H.L.; Mostafa, T.B. Synthesis of Polyvinyl Alcohol/Maleic Acid Hydrogels by Electron Beam Irradiation for Dye Uptake. J. Macromol. Sci. 2013, 50, 6-17. [CrossRef]

28. Abualnaja, K.M.; Alprol, A.E.; Ashour, M.; Mansour, A.T. Influencing Multi-Walled Carbon Nanotubes for the Removal of Ismate Violet 2R Dye from Wastewater: Isotherm, Kinetics, and Thermodynamic Studies. Appl. Sci. 2021, 11, 4786. [CrossRef]

29. Parvin, M. Adsorption of Dyes on Activated Carbon from Agricultural Wastes; United Arab Emirates University: Anaien, United Arab Emirates, 2015.

30. Ludwig, G.M.; Perschbacher, P.; Edziyie, R.; No, S. The effect of the dye Aquashade ${ }^{\circledR}$ on water quality, phytoplankton, zooplankton, and sunshine bass, Morone chrysops $\times$ M. saxatilis, fingerling production in fertilized culture ponds. J. World Aquac. Soc. 2010, 41, 40-48. [CrossRef]

31. Ushakumary, E.R. Waste Water Treatment Using Low Cost Natural Adsorbents. Ph.D. Thesis, Cochin University of Science and Technology Kochi, Kerala, India, April 2013.

32. Langmuir, I. The constitution and fundamental properties of solids and liquids. Part II.-Liquids. J. Am. Chem. Soc. 1917, 39, 1848-1906. [CrossRef]

33. Freundlich, H. Über die Adsorption in Lösungen. Habilitationsschrift Durch Welche... zu Haltenden Probevorlesung "Kapillarchemie und Physiologie" Einladet Dr. Herbert Freundlich; Wilhelm Engelmann: Leipzig, Germany, 1906.

34. Dada, A.O.; Olalekan, A.P.; Olatunya, A.M.; DADA, O. Langmuir, Freundlich, Temkin and Dubinin-Radushkevich Isotherms Studies of Equilibrium Sorption of Zn 2+ Unto Phosphoric Acid Modified Rice Husk. IOSR J. Appl. Chem. 2012, 3, 38-45. [CrossRef] 
35. McKay, G.; Blair, H.S.; Gardner, J.R. Adsorption of dyes on chitin. I. Equilibrium studies. J. Appl. Polym. Sci. 1982, $27,3043-3057$. [CrossRef]

36. Abinandan, S.; Subashchandrabose, S.R.; Pannerselvan, L. Bioresource Technology Potential of acid-tolerant microalgae, Desmodesmus sp. MAS1 and Heterochlorella sp. MAS3, in heavy metal removal and biodiesel production at acidic pH. Bioresour. Technol. 2019, 278, 9-16. [CrossRef] [PubMed]

37. Özacar, M.; Şengil, I.A. Adsorption of reactive dyes on calcined alunite from aqueous solutions. J. Hazard. Mater. 2003, 98, 211-224. [CrossRef]

38. Chandía, N.P.; Matsuhiro, B. Characterization of a fucoidan from Lessonia vadosa (Phaeophyta) and its anticoagulant and elicitor properties. Int. J. Biol. Macromol. 2008, 42, 235-240. [CrossRef] [PubMed]

39. Swaminathan, S.; Muthumanickkam, A.; Imayathamizhan, N.M. An effective removal of methylene blue dye using polyacrylonitrile yarn waste/graphene oxide nanofibrous composite. Int. J. Environ. Sci. Technol. 2015, 12, 3499-3508. [CrossRef]

40. Abualnaja, K.M.; Alprol, A.E.; Ashour, M. Removing of Anionic Dye from Aqueous Solutions by Adsorption Using of Multiwalled Carbon Nanotubes and Poly (Acrylonitrile-styrene) Impregnated with Activated Carbon. Sustainability 2021, 13, 7077. [CrossRef]

41. Jebapriya, G.R.; Gnanadoss, J.J. Bioremediation of textile dye using white rot fungi: A Review. Int. J. Curr. Res. Rev. 2013, 5, 1-12.

42. Kareem, A.; Alrazak, N.A.; Aljebori, K.H.; Aljeboree, A.M.; Algboory, H.L.; Alkaim, A.F. Removal of methylene blue dye from aqueous solutions by using activated carbon/ureaformaldehyde composite resin as an adsorbent. Int. J. Chem. Sci. 2016, 14, 635-648.

43. Ali, D. Single and Binary Adsorption of Reactive Blue and Red Dyes Onto Activated Carbon. Int. J. Eng. Innov. Res. 2014, 3, 642-649.

44. Prol, A.; Azzem, M.; Amer, A.; El-Metwally, M.; El-Hamid, H.; El-Moselhy, K. Adsorption of Cadmium (II) Ions (II) from Aqueous Solution onto Mango Leaves. Asian J. Phys. Chem. Sci. 2017, 2, 1-11. [CrossRef]

45. Aksu, Z.; Tezer, S. Biosorption of reactive dyes on the green alga Chlorella vulgaris. Process. Biochem. 2005, 40, 1347-1361. [CrossRef]

46. Abomohra, A.E.-F.; El-Hefnawy, M.E.; Wang, Q.; Huang, J.; Li, L.; Tang, J.; Mohammed, S. Sequential bioethanol and biogas production coupled with heavy metal removal using dry seaweeds: Towards enhanced economic feasibility. J. Clean. Prod. 2021, 316, 128341. [CrossRef]

47. Ashour, M.; El-Shafei, A.A.; Khairy, H.M.; Abd-Elkader, D.Y.; Mattar, M.A.; Alataway, A.; Hassan, S.M. Effect of Pterocladia capillacea Seaweed Extracts on Growth Parameters and Biochemical Constituents of Jew's Mallow. Agronomy 2020, 10, 420. [CrossRef]

48. Ashour, M.; Mabrouk, M.M.; Ayoub, H.F.; El-Feky, M.M.; Zaki, S.Z.; Hoseinifar, S.H.; Rossi, W.; Van Doan, H.; El-Haroun, E.; Goda, A.M.S. Effect of dietary seaweed extract supplementation on growth, feed utilization, hematological indices, and non-specific immunity of Nile Tilapia, Oreochromis niloticus challenged with Aeromonas hydrophila. J. Appl. Phycol. 2020, 32, 3467-3479. [CrossRef]

49. Calvete, T.; Lima, E.C.; Cardoso, N.F.; Vaghetti, J.C.P.; Dias, S.L.P.; Pavan, F.A. Application of carbon adsorbents prepared from Brazilian-pine fruit shell for the removal of reactive orange 16 from aqueous solution: Kinetic, equilibrium, and thermodynamic studies. J. Environ. Manag. 2010, 91, 1695-1706. [CrossRef]

50. Royer, B.; Cardoso, N.F.; Lima, E.C.; Macedo, T.R.; Airoldi, C. A useful organofunctionalized layered silicate for textile dye removal. J. Hazard. Mater. 2010, 181, 366-374. [CrossRef]

51. Aksu, Z.; Tezer, S. Equilibrium and kinetic modelling of biosorption of Remazol black B by Rhizopus arrhizus in a batch system: Effect of temperature. Process. Biochem. 2000, 36, 431-439. [CrossRef]

52. Aksu, Z.; Isoglu, I.A. Use of dried sugar beet pulp for binary biosorption of Gemazol Turquoise Blue-G reactive dye and copper(II) ions: Equilibrium modeling. Chem. Eng. J. 2007, 127, 177-188. [CrossRef]

53. Dogar, Ç.; Gürses, A.; Açıkyıldız, M.; Özkan, E. Thermodynamics and kinetic studies of biosorption of a basic dye from aqueous solution using green algae Ulothrix sp. Colloids Surf. 2010, 76, 279-285. [CrossRef]

54. Celekli, A.; İlgün, G.; Bozkurt, H. Sorption equilibrium, kinetic, thermodynamic, and desorption studies of Reactive Red 120 on Chara contraria. Chem. Eng. J. 2012, 191, 228-235. [CrossRef]

55. Ergene, A.; Ada, K.; Tan, S.; Katırcıoğlu, H. Removal of Remazol Brilliant Blue R dye from aqueous solutions by adsorption onto immobilized Scenedesmus quadricauda: Equilibrium and kinetic modeling studies. Desalination 2009, 249, 1308-1314. [CrossRef]

56. Celekli, A.; Tanrıverdi, B.; Bozkurt, H. Predictive modeling of removal of Lanaset Red G on Chara contraria; kinetic, equilibrium, and thermodynamic studies. Chem. Eng. J. 2011, 169, 166-172. [CrossRef]

57. Mahmoud, A.S.; Ghaly, A.E.; Brooks, S.L. Influence of temperature and pH on the stability and colorimetric measurement of textile dyes. Am. J. Biochem. Biotechnol. 2007, 3, 33-41. [CrossRef]

58. Carneiro, P.A.; Osugi, M.E.; Fugivara, C.S.; Boralle, N.; Furlan, M.; Zanoni, M.V.B. Evaluation of different electrochemical methods on the oxidation and degradation of Reactive Blue 4 in aqueous solution. Chemosphere 2005, 59, 431-439. [CrossRef] [PubMed]

59. Nagendrappa, G. An epitome of K Venkataraman's chemistry. Resonance 2004, 9, 45-51. [CrossRef]

60. Al-Ghouti, M.A.; Khraisheh, M.A.M.; Allen, S.J.; Ahmed, M.N. The removal of dyes from textile wastewater: A study of physical characteristics and adsorption mechanisms of diatomaceous earth. J. Environ. Manag. 2003, 69, 230-237. [CrossRef] [PubMed]

61. Al Prol, A.E. Study of Environmental Concerns of Dyes and Recent Textile Effluents Treatment Technology: A Review. Asian, J. Fish. Aquat. Res. 2019, 3, 1-18. [CrossRef] 
62. Halsey, G. Physical adsorption on non-uniform surfaces. J. Chem. Phys. 1948, 16, 931-937. [CrossRef]

63. Gupta, V.K.; Rastogi, A. Biosorption of hexavalent chromium by raw and acid-treated green alga Oedogonium hatei from aqueous solutions. J. Hazard. Mater. 2009, 163, 396-402. [CrossRef]

64. Suski, J.G.; Swan, C.M.; Salice, C.J.; Wahl, C.F. Effects of pond management on biodiversity patterns and community structure of zooplankton in urban environments Science of the Total Environment Effects of pond management on biodiversity patterns and community structure of zooplankton in urban environme. Sci. Total Environ. 2018, 619-620, 1441-1450. [CrossRef] [PubMed]

65. Verma, A.K.; Choudhary, A. Effect of heavy metal toxicity on Zooplankton population based on dyes and printing industries in Jodhpur (Rajasthan). Biolife 2017, 5, 69-73. [CrossRef] 